OAK RIDGE

ORNL/TM-2015/284

NATIONAL LABORATORY

MANAGED BY UT-BATTELLE

FOR THE DEPARTMENT OF ENERGY

\title{
Report on FY15 Two-Bar Thermal Ratcheting Test Results
}

June 22, 2015

Prepared by

Yanli Wang, Robert I. Jetter, Seth T. Baird, Chao Pu and T.-L. Sham

Approved for public release; distribution is unlimited.

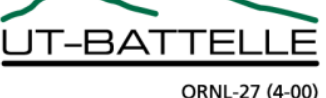




\section{DOCUMENT AVAILABILITY}

Reports produced after January 1, 1996, are generally available free via the U.S. Department of Energy (DOE) Information Bridge.

Web site http://www.osti.gov/bridge

Reports produced before January 1, 1996, may be purchased by members of the public from the following source.

National Technical Information Service

5285 Port Royal Road

Springfield, VA 22161

Telephone 703-605-6000 (1-800-553-6847)

TDD 703-487-4639

Fax 703-605-6900

E-mail info@ntis.gov

Web site http://www.ntis.gov/support/ordernowabout.htm

Reports are available to DOE employees, DOE contractors, Energy Technology Data Exchange (ETDE) representatives, and International Nuclear Information System (INIS) representatives from the following source.

Office of Scientific and Technical Information

P.O. Box 62

Oak Ridge, TN 37831

Telephone 865-576-8401

Fax 865-576-5728

E-mail reports@osti.gov

Web site http://www.osti.gov/contact.html

This report was prepared as an account of work sponsored by an agency of the United States Government. Neither the United States Government nor any agency thereof, nor any of their employees, makes any warranty, express or implied, or assumes any legal liability or responsibility for the accuracy, completeness, or usefulness of any information, apparatus, product, or process disclosed, or represents that its use would not infringe privately owned rights. Reference herein to any specific commercial product, process, or service by trade name, trademark, manufacturer, or otherwise, does not necessarily constitute or imply its endorsement, recommendation, or favoring by the United States Government or any agency thereof. The views and opinions of authors expressed herein do not necessarily state or reflect those of the United States Government or any agency thereof. 
ORNL/TM-2015/284

Report on FY15 Two-Bar Thermal Ratcheting Test Results

Yanli Wang, Robert I. Jetter* Seth T. Baird, Chao Pu** and T.-L. Sham

* Consultant

** University of Tennessee, Knoxville

Date Published: June 22, 2015

Prepared under the direction of the

U.S. Department of Energy

Office of Nuclear Energy

Advanced Reactor Technologies Program

\author{
Prepared by \\ OAK RIDGE NATIONAL LABORATORY \\ Oak Ridge, Tennessee 37831-6283 \\ managed by \\ UT-BATTELLE, LLC \\ for the \\ U.S. DEPARTMENT OF ENERGY \\ under contract DE-AC05-00OR22725
}


Page Intentionally Blank 


\section{ACKNOWLEDGMENTS}

This research was sponsored by the U.S. Department of Energy (DOE), Office of Nuclear Energy (NE), for the Advanced Reactor Technologies (ART) Program. We gratefully acknowledge the support provided by Carl Sink of DOE-NE, Advanced Reactor Technologies, ART Program Manager; William Corwin of DOE-NE, ART Materials Technology Lead; David Petti of Idaho National Laboratory (INL), ART Co-National Technical Director; and Richard Wright of INL, Technical Lead, High Temperature Materials.

Helpful discussion with Peter Carter of Stress Engineering Services, Inc. is gratefully acknowledged. The contribution of Shane Hawkins of the Oak Ridge National Laboratory (ORNL) in this testing program by setting up and running some of the experiments is greatly appreciated. David Thomas of ORNL configured the hardware for coupling two servo-hydraulic machines and Donald Erdman of ORNL programmed the controls and established the initial experimental setup. The time spent by Hong Wang of ORNL in reviewing this report is also greatly appreciated.

We would also like to acknowledge Richard Wright of INL for supplying the Alloy 617 materials to support the testing task of this work. 
Page Intentionally Blank 


\section{EXECUTIVE SUMMARY}

Alloy 617 is a reference structural material for very high temperature components of advanced-gas cooled reactors with outlet temperatures in the range of $900-950^{\circ} \mathrm{C}$. In order for designers to be able to use Alloy 617 for these high temperature components, Alloy 617 has to be approved for use in Section III (the nuclear section) of the American Society of Mechanical Engineers (ASME) Boiler and Pressure Vessel Code. A plan has been developed to submit a draft code for Alloy 617 to ASME Section III by 2015. However, the current rules in Subsection $\mathrm{NH}^{*}$ for the evaluation of strain limits and creep-fatigue damage using simplified methods based on elastic analysis have been deemed inappropriate for Alloy 617 at temperatures above $1200^{\circ} \mathrm{F}\left(650^{\circ} \mathrm{C}\right)$. The rationale for this exclusion is that at higher temperatures it is not feasible to decouple plasticity and creep deformation, which is the basis for the current simplified rules. This temperature, $1200^{\circ} \mathrm{F}\left(650^{\circ} \mathrm{C}\right)$, is well below the temperature range of interest for this material in High Temperature Gas Cooled Reactor (HTGR) applications. The only current alternative is, thus, a full inelastic analysis which requires sophisticated material models which have been formulated but not yet verified. To address this issue, proposed code rules have been developed which are based on the use of elastic-perfectly plastic (EPP) analysis methods and which are expected to be applicable to very high temperatures. These newly proposed rules also address a long-term objective to provide an option for more simple, comprehensive and easily applied rules than the current so called "simplified" rules.

These two-bar tests discussed herein are part of an ongoing series of tests with cyclic loading at high temperatures using specimens representing key features of potential component designs. The initial focus of the two-bar ratcheting test program, to verify the procedure for evaluation of strain limits for Alloy 617 at very high temperatures, has been expanded to respond to guidance from ASME Code committees that the proposed EPP methodology should also apply to other Subsection NH materials throughout their allowed temperature range. To support these objectives, two suites of tests have been accomplished during this reporting period. One suite addresses the issue of the response of Alloy 617 at a lower temperature with tests in range of $500-800^{\circ} \mathrm{C}$ and a few at $350-650^{\circ} \mathrm{C}$. The other suite addresses the response of $\mathrm{SS} 316 \mathrm{H}$ up to its current maximum allowed temperature of $1500^{\circ} \mathrm{F}\left(815^{\circ} \mathrm{C}\right)$

In the two-bar test methodology, the two bars can be viewed as specimens taken out of a tubular component across the wall thickness representing the inner wall element and the outer wall element respectively. The two bars are alternately heated and cooled under sustained axial loading to generate ratcheting. A sustained hold time is introduced at the hot extreme of the cycle to capture the accelerated ratcheting and strain accumulation due to creep. Since the boundary conditions are a combination of strain control and load control it is necessary to use two coupled servo-controlled testing machines to achieve the key features of the two-bar representation of actual component behavior.

Two-bar thermal ratcheting test results with combinations of applied mean stresses, transient temperature difference and heating and cooling rates were recorded. Tests performed at heating and cooling rates of $30^{\circ} \mathrm{C} / \mathrm{min}$ are comparable to a strain rate of $10^{-5} / \mathrm{sec}$. At high mean stresses in tension the direction of ratcheting was in-phase with the load, e.g. tensile strain ratcheting under high tensile loading; however, at lower loads, strain ratcheting in compression was observed under net tensile mean stresses. The strain accumulation was proportional to the applied thermal load. However, there was a narrow range of applied load in which the high applied thermal loading did not result in significant strain accumulation. Unfortunately, when the proposed EPP strain limit evaluation rules were applied to the loading history for the two-bar configuration, the predicted narrow range of low strain accumulation did not coincide with the experimental data. However, by the use of inelastic analysis in conjunction with an analytic "experiment" it was possible to show that the EPP strain limit code case rules could be applied to high temperature structures where the stress and temperature is not uniform throughout - which is the general case. 
Interestingly, the suite of tests on Alloy 617 at the lower temperature range of $500^{\circ} \mathrm{C}$ to $800^{\circ} \mathrm{C}$ showed good agreement with the proposed EPP strain limit rules with a much wider band of applied load that exhibited minimal ratcheting. The four tests conducted at the lower temperature range of $350^{\circ} \mathrm{C}$ to $650^{\circ} \mathrm{C}$ showed no ratcheting. The suite of tests on $\mathrm{SS} 316 \mathrm{H}$ at a temperature range of $515^{\circ} \mathrm{C}$ to $815^{\circ} \mathrm{C}$ resembled the results from the tests on Alloy 617 at $650^{\circ} \mathrm{C}$ to $950^{\circ} \mathrm{C}$. Both exhibited a narrow band of applied load where the strain was limited and neither agreed with the envelope of $1 \%$ predicted strain which is the limit for acceptability under the rules of Subsection NH.

*Subsection NH will be incorporated in Section III, Div. 5, Subsection HBB effective with the 2015 edition of the ASME B\&PV Code to be released in July 2015. Since this new issue is not generally available as of the release of this report, the references to Subsection NH will be maintained herein. 


\section{CONTENTS}

CONTENT .

PAGE

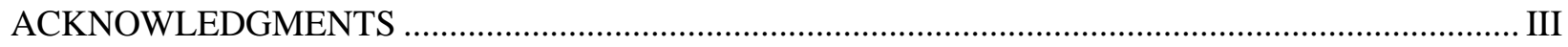

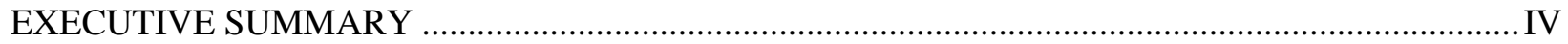

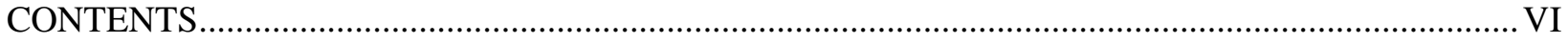

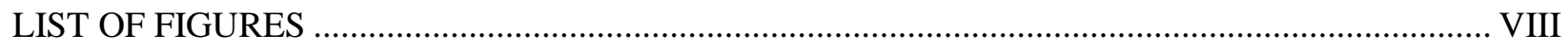

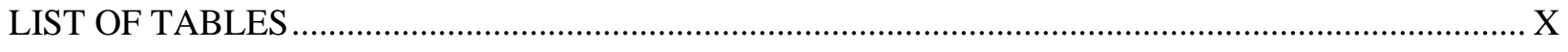

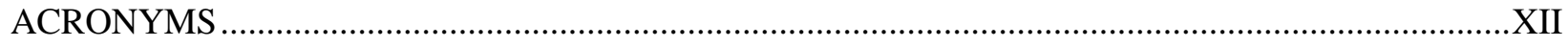

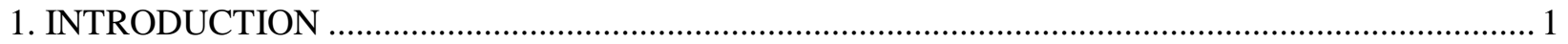

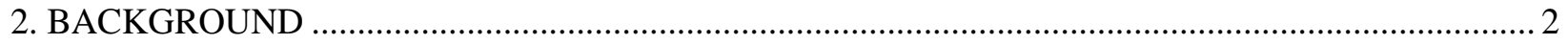

3. TWO-BAR THERMAL RATCHETING EXPERIMENTS AND PREVIOUS RESULTS .................... 3

4. CURRENT TWO-BAR THERMAL RACHETING TEST RESULTS …......................................... 10

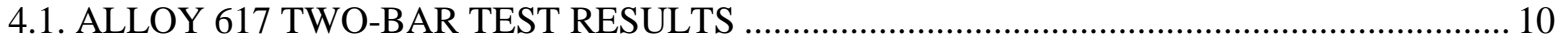

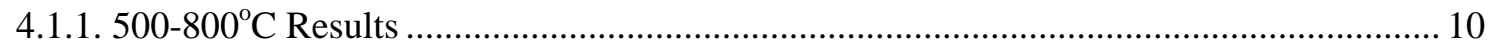

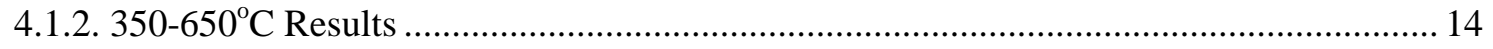

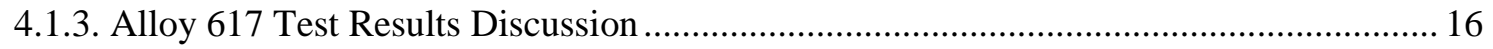

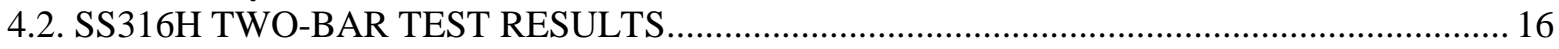

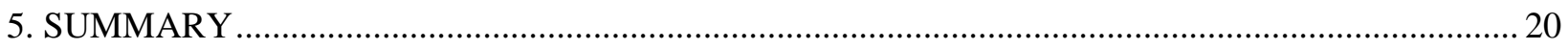

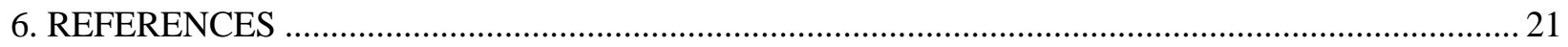


Intentionally Blank 


\section{LIST OF FIGURES}

FIGURE

PAGE

FIG. 1. PRESSURIZED CYLINDER WITH RADIAL THERMAL GRADIENT (A) AND THE EQUIVALENT TWO-BAR MODEL (B)

FIG. 2. EXPERIMENTAL SETUP WITH THE IGNITER HEATER

FIG. 3. OPTICAL IMAGES OF THE AS-RECEIVED SS316H. 5

FIG. 4. SPECIMEN GEOMETRY OF ALLOY 617 AND SS316H USED IN TWO-BAR THERMAL RATCHETING EXPERIMENTS.

FIG. 5. TEMPERATURE VS. TIME HISTOGRAM FOR TWO-BAR THERMAL RATCHETING EXPERIMENTS

FIG. 6. TWO BAR TEST DATA WITH 1\% DESIGN ENVELOPE PREDICTIONS FROM THE

STRAIN LIMITS CODE CASE AND INELASTIC ANALYSIS (ALLOY 617 WITH TESTING TEMPERATURE RANGE OF $650^{\circ} \mathrm{C}$ TO $\left.950^{\circ} \mathrm{C}\right)$.

FIG. 7. SUMMARY OF E-PP AND CREEP ANALYSIS LOAD CASES ON BREE PLOT OF NORMALIZED PRIMARY AND THERMAL STRESS.

FIG. 8. TWO BAR TEST DATA WITH 1\% DESIGN ENVELOPE PREDICTIONS FROM THE STRAIN LIMITS CODE CASE.

FIG. 9. STRESS VS MECHANICAL STRAIN FOR ALLOY 617 WITH NOMINAL 100LBS TOTAL LOAD AND 10MIN TIME DELAY FOR TEST T17-1 $\left(650^{\circ} \mathrm{C}\right.$ TO $\left.950^{\circ} \mathrm{C}(\mathrm{A})\right)$ AND TEST T20-12(500 ${ }^{\circ} \mathrm{C}$ TO $\left.800^{\circ} \mathrm{C}(\mathrm{B})\right)$

FIG. 10. STRESS VS TIME FOR ALLOY 617 WITH NOMINAL 100LBS TOTAL LOAD AND 10MIN TIME DELAY FOR TEST T17- $1\left(650^{\circ} \mathrm{C}\right.$ TO $\left.950^{\circ} \mathrm{C}(\mathrm{A})\right)$ AND TEST T20-12 $\left(500^{\circ} \mathrm{C}\right.$ TO $\left.800^{\circ} \mathrm{C}(\mathrm{B})\right)$

FIG. 11. TWO BAR TEST DATA WITH 1\% DESIGN ENVELOPE PREDICTIONS FROM THE STRAIN LIMITS CODE CASE (ALLOY 617 WITH TESTING TEMPERATURE RANGE OF $350^{\circ} \mathrm{C}$ TO $650^{\circ} \mathrm{C}$ )

FIG. 12. STRESS VS TIME FOR ALLOY 617 WITH NOMINAL 150LBS TOTAL LOAD AND 10MIN TIME DELAY AT TEMPERATURE RANGE OF $350^{\circ} \mathrm{C}$ TO $650^{\circ} \mathrm{C}$

FIG. 13. STRESS VS MECHANICAL STRAIN FOR ALLOY 617 WITH NOMINAL 150LBS TOTAL LOAD AND 10MIN TIME DELAY $\left(350^{\circ} \mathrm{C}-650^{\circ} \mathrm{C}\right)$

FIG. 14. TWO BAR TEST DATA WITH 1\% DESIGN ENVELOPE PREDICTIONS FROM THE STRAIN LIMITS CODE CASE AND INELASTIC ANALYSIS (SS316H WITH TESTING TEMPERATURE RANGE OF $515^{\circ} \mathrm{C}$ TO $\left.815^{\circ} \mathrm{C}\right)$

FIG. 15. STRESS VS MECHANICAL STRAIN FOR SS316H FOR TEST T23-1 FOR CYCLIC TEMPERATURE RANGE $515-815^{\circ} \mathrm{C}$

FIG. 16. STRESS VS TIME FOR SS316H FOR TEST T23-1 FOR CYCLIC TEMPERATURE RANGE $515-815^{\circ} \mathrm{C}$ 
Intentionally Blank 


\section{LIST OF TABLES}

TABLE PAGE

TABLE 1. CHEMICAL COMPOSITION OF ALLOY 617 PLATE WITH HEAT NUMBER 314626 (WEIGHT \%). .5

TABLE 2. CHEMICAL COMPOSITIONS OF SS316H BAR WITH HEAT NUMBER 101076 (WEIGHT \%) .5

TABLE 3. SUMMARY OF PRIOR TWO-BAR THERMAL RATCHETING EXPERIMENTS ON ALLOY 617 FOR TEMPERATURE RANGE OF $650^{\circ} \mathrm{C}$ TO $950^{\circ} \mathrm{C}$

TABLE 4. SUMMARY OF TWO-BAR THERMAL RATCHETING EXPERIMENTS ON ALLOY 617 FOR TEMPERATURE RANGE OF $500-800^{\circ} \mathrm{C}$ 10

TABLE 5. SUMMARY OF TWO-BAR THERMAL RATCHETING EXPERIMENTS ON ALLOY 617 FOR TEMPERATURE RANGE OF $350-650^{\circ} \mathrm{C}$ 14

TABLE 6. SUMMARY OF TWO-BAR THERMAL RATCHETING EXPERIMENTS ON SS316H FOR TEMPERATURE RANGE OF $515^{\circ} \mathrm{C}$ TO $815^{\circ} \mathrm{C}$ 
Intentionally Blank 


\section{ACRONYMS}

ASME

ANL

CRBR

DOE

EPP

HTGR

IHX

INL

LMFBR

ORNL

SMR

VHTR
American Society of Mechanical Engineers

Argonne National Laboratory

Clinch River Breeder Reactor

Department of Energy

Elastic-Perfectly Plastic

High Temperature Gas-cooled Reactor

Intermediate Heat Exchanger

Idaho National Laboratory

Liquid Metal-Cooled Fast Breeder Reactor

Oak Ridge National Laboratory

Small Module Reactor

Very High Temperature Reactor 
Intentionally Blank 


\section{INTRODUCTION}

Alloy 617 is a reference structural material for very high temperature components of advanced-gas cooled reactors with outlet temperatures in the range of $900-950^{\circ} \mathrm{C}$. In order for designers to be able to use Alloy 617 for these high temperature components, Alloy 617 has to be approved for use in Section III (the nuclear section) of the American Society of Mechanical Engineers (ASME) Boiler and Pressure Vessel Code. A plan has been developed to submit a draft code for Alloy 617 to ASME Section III by 2015. There has not been a new high temperature material approved for use in Section III for almost 20 years. The Alloy 617 Code Case effort would also lead the way to establish a path for code qualification of new high temperature materials of interest for other advanced Small Module Reactors (SMR).

The current rules in Subsection NH for the evaluation of strain limits and creep-fatigue damage using simplified methods based on elastic analysis have been deemed inappropriate for Alloy 617 at temperatures above $1200^{\circ} \mathrm{F}\left(650^{\circ} \mathrm{C}\right)$ (Corum and Blass, 1991). The rationale for this exclusion is that at higher temperatures it is not feasible to decouple plasticity and creep deformation, which is the basis for the current simplified rules. This temperature, $1200^{\circ} \mathrm{F}\left(650^{\circ} \mathrm{C}\right)$, is well below the temperature range of interest for this material for the High Temperature Gas Cooled Reactor (HTGR). The only current alternative is, thus, a full inelastic analysis which requires sophisticated material models which have been formulated but not yet verified. An additional impediment to the use of full inelastic analysis is the level of expertise and experience required to implement these models and interpret the results.

To address this issue, proposed code rules have been developed which are based on the use of elasticperfectly plastic (EPP) analysis methods and which are expected to be applicable to very high temperatures with the range $900-950^{\circ} \mathrm{C}$ as well as lower temperatures. These newly proposed rules also address a long-term objective to provide an option for more simple, comprehensive and easily applied rules than the current so called "simplified" rules.

These two-bar tests discussed herein are part of an ongoing series of tests with cyclic loading at high temperatures using specimens representing key features of potential component designs. The initial focus of the two-bar ratcheting test program, to verify the procedure for evaluation of strain limits for Alloy 617 at very high temperatures, has been expanded to respond to guidance from ASME Code committees that the proposed EPP methodology should also apply to other Subsection NH materials throughout their allowed temperature range. To support these objectives, two suites of tests have been accomplished during this reporting period. One suite addresses the issue of the response of Alloy 617 at a lower temperature with tests in range of $500-800^{\circ} \mathrm{C}$ and a few at $350-650^{\circ} \mathrm{C}$. The other suite addresses the response of SS316H up to its current maximum allowed temperature of $1500^{\circ} \mathrm{F}\left(815^{\circ} \mathrm{C}\right)$.

The two-bar test concept was initiated to support high temperature design criteria for the Clinch River Breeder Reactor (CRBR). The goal of the two-bar test is to simulate the thermal ratcheting failure mode which is the basis of the strain limit design criteria in Subsection NH of Section III. This type of testing was originally performed on $2 \frac{1}{4} \mathrm{Cr}$-1Mo steel (Swindeman, et al., 1982) to support the verification of the recommended constitutive equations for liquid metal-cooled fast breeder reactor (LMFBR) applications. However, the current high temperature two-bar test results will also, initially, be used to validate the newly proposed simplified methodology for assessment of strain limits at very high temperatures where the current NH methodology has been deemed inappropriate for Alloy 617 and for other NH Subsection NH materials, including Alloy 617, throughout their elevated temperature operating regime.

In the two-bar test methodology, the two bars can be viewed as specimens taken out of a tubular component across the wall thickness representing the inner wall element and the outer wall element. The two bars are alternately heated and cooled under sustained axial loading to generate ratcheting. A sustained hold time is introduced at the hot extreme of the cycle to capture the accelerated ratcheting and 
strain accumulation due to creep. Since the boundary conditions are a combination of strain control and load control it is necessary to use two coupled servo-controlled testing machines to achieve the key features of the two-bar representation of actual component behavior.

The preceding work on the two-bar test program by Wang et. al. (2013) was focused on establishing the two-bar thermal ratcheting test procedure for Alloy 617 and the evaluation of the material ratcheting behavior at relatively slow imposed heating and cooling thermal transient rates of $5^{\circ} \mathrm{C} / \mathrm{min}$. These rates were compatible with heating and cooling rates achievable with existing heaters and measurement and control system characteristics. However, there was an incentive to test at implied strain rates compatible with creep-fatigue tests that have been conducted for Alloy 617 by Carrol et al. $(2010,2013)$ in support of its codification in Section III of the ASME Boiler and Pressure Vessel Code. Although most of the creepfatigue tests were performed at a strain rate of $10^{-3} / \mathrm{sec}$ in those test programs, there are data available at a strain rate of $10^{-5} / \mathrm{sec}$ that are comparable to the $30^{\circ} \mathrm{C} / \mathrm{min}$ thermal transient rates employed in this phase of the Two-bar test program. Accordingly, modifications were made which enabled testing at $30^{\circ} \mathrm{C} / \mathrm{min}$. In addition, in assessing the test results from preceding work of the thermal ratcheting study on Alloy 617, testing parameters were refined and focused on the conditions that were most relevant to the development of design rules for strain limits at very high temperatures.

\section{BACKGROUND}

The current high temperature design rules in Subsection NH consider two basic categories of load application. The first is called load controlled and represents the stresses that are in equilibrium with externally applied loads and moments. A basic example is the stress in the wall of a pressure vessel due to an internal pressure, remote from structural discontinuities. These stresses generally dictate required wall thickness. The second basic category is identified as displacement controlled. In this category are stress levels generated at local structural discontinuities and by restrained thermal expansion. An example would be the thermal stress in the wall of a vessel due to a radial thermal gradient. The basic characteristic of these stresses is that, when combined with load controlled stresses, they limit the number of cycles that a component can withstand without cracking or distortion. Displacement controlled stress limits are based on limiting the amount of strain that can accumulate and the number of cyclic loadings that can be applied without cracking. The former are called strain limits and the latter, creep-fatigue damage. Separate design criteria are used to evaluate strain limits and creep-fatigue and the focus of the two-bar ratcheting test program is verification of the procedure for evaluation of strain limits at very high temperatures.

Although creep-fatigue damage accumulation is often the critical failure mode for elevated temperature structures, strain limits are frequently design limiting and, additionally, satisfaction of the strain limits criteria is prerequisite to consideration of creep-fatigue limits in the current rules in Subsection NH.

However, there is a problem with the current rules for strain limits. Two methods are currently provided. One is based on a complete modeling of the response of the structure throughout the life of the component to generate stress and strain histories from which the accumulated strain and creep-fatigue damage can be ascertained. Although conceptually straightforward, there are many practical difficulties in this approach; one of the most critical is that it is necessary to correctly account in full detail for all of the material behaviors over a wide range of temperatures and loading histories and go through a process of validating these complex constitutive models. The other method is to rely on mechanistic models based on the results of elastic analysis to bound the true inelastic response of the structure. These are usually referred to as simplified methods, although they can be quite complex in practice, because they are based on the much simpler assumed elastic material model. 
The current simplified methods for evaluation of strain limits are based on the potential incremental distortion or ratcheting that occurs in a pressurized cylinder when subjected to cyclic through wall thermal gradients. This model development is attributed to Bree (1967) and was extended by O'Donnell and Porowsky (1991) to recognize that the strain in the cylinder could be bounded by the elastically calculated core stress in the wall provided that it was less than yield. This concept was further extended by Sartory (1989) to handle non-linear thermal gradients and strain concentrations. However, the common feature of all these methods is that they are based on the concept that inelastic strains due to time dependent creep can be accounted for separately from time independent plastic strain. In fact, the elastically calculated parameters in these methods are implementable for a variety of materials because they are normalized by the yield strength. However, at very high temperatures time dependent creep and time independent plasticity are indistinguishable and there is not a uniform yield strength at a given temperature but in effect, a series of effective yield strengths that are strain rate and stress history dependent. It is for these reasons that the current simplified methods in Subsection NH were deemed inappropriate for Alloy 617 at temperatures above $1200^{\circ} \mathrm{F}\left(650^{\circ} \mathrm{C}\right)$.

To address this dilemma, and to provide a simpler, more effective approach to evaluation of strain limits, a cyclic elastic-perfectly plastic analysis method has been proposed which provides a conservative estimate of cyclic creep strain accumulation within the ratchet boundary. The method is to check for ratcheting based on an elastic-perfectly plastic material model with a temperature-dependent pseudo yield stress defined by temperature, time and stress to give $1 \%$ accumulated inelastic strain. It does not require stress classification and is also applicable to a full range of temperatures above and below the creep regime. The development and justification of this methodology is documented in Carter et al. (2012).

Since the "yield strength" used in the analysis is not an actual yield strength but, rather, a pseudo yield strength that represents the time and stress to give $1 \%$ accumulated inelastic strain; it avoids the issue of strain rate dependent yield strength and the lack of distinction between plasticity and creep at very high temperatures. The use of this methodology is part of the plan to gain approval of a code case for the use of Alloy 617 at temperatures up to and including $950^{\circ} \mathrm{C}$ for Class I (or Class A in Section III, Division 5 terminology) components. The primary purpose of the two-bar test program is to provide experimental data to verify the proposed new rules. However, this data can also be used to develop, refine and validate the elevated temperature constitutive material models which would be used to perform full inelastic analysis if the simplified method were too conservative for a particular component design configuration and operating conditions.

\section{TWO-BAR THERMAL RATCHETING EXPERIMENTS AND PREVIOUS RESULTS}

The test procedure of two-bar thermal ratcheting was developed and presented in detail in the preceding report by Wang et al. (2013, 2014). As schematically shown in Fig. 1, the two bars can be viewed as specimens taken out of a tubular component across the wall thickness representing the inner and outer wall elements. The through wall temperature gradient, $\Delta T$, is represented by the temperature difference between the bars. The sustained pressure load, $F$, is generated by the internal pressure, $P$, and it is represented by total load on the two bars. The combined thermal transients and sustained pressure load can generate a ratchet (progressive deformation) mechanism.

The control logic used is similar to what was reported by Swindeman et al. (1982). In this method, two coupled servo-controlled machines are used to implement two bars in a parallel testing condition and the control system forces equal strains in the two specimens, yet allows the applied total load to be constant. The testing concept for two bars in parallel was demonstrated for various mean stresses and thermal histories for Alloy 617 by Wang et al. (2013, 2014), among which, the low mean stress conditions were identified to be most interesting for verification of the Elastic Perfect-Plastic (EPP) 
methodology for strain limits design criteria.

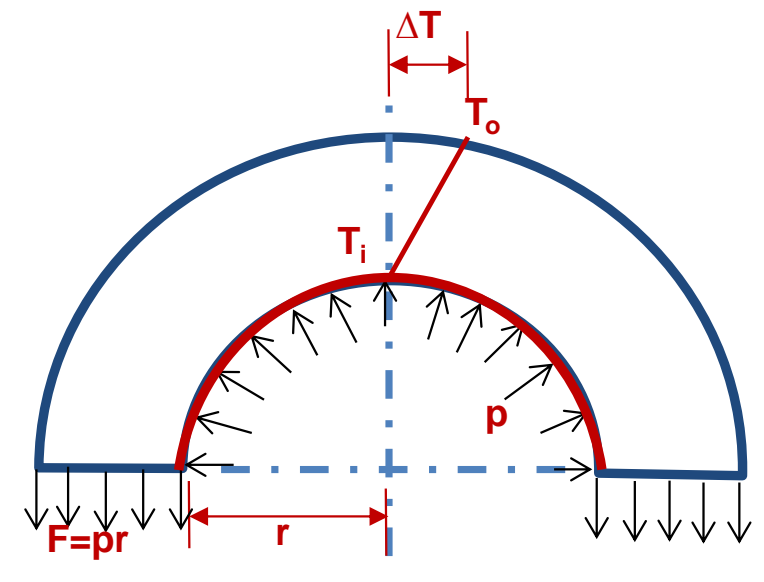

(a)

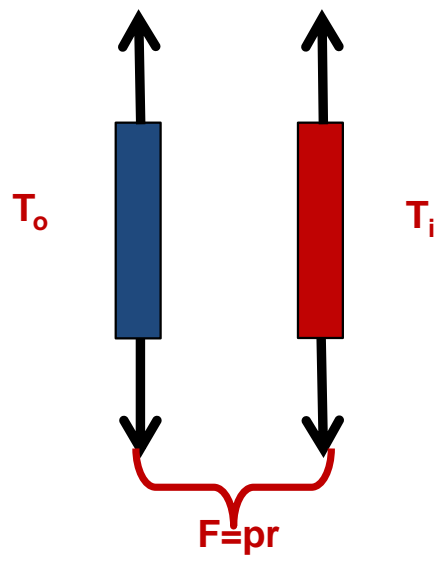

(b)

Fig. 1. Pressurized cylinder with radial thermal gradient (a) and the equivalent two-bar model (b)

In this study, the heating systems were replaced with heaters made of igniter heating elements that are capable of faster heating and cooling rates of $30^{\circ} \mathrm{C} / \mathrm{min}$ as compared to the previous tests performed at $5^{\circ} \mathrm{C} / \mathrm{min}$. A picture of the experimental setup for one of the bars is shown in Fig. 2. The top and bottom tabs of the specimen are attached with heating coils to achieve three-zone temperature control. The thermal loading cycles are controlled and automated by LabView software. The temperature difference within the gage length of the specimen was less than $1 \%$ of the target temperature. Additionally, the thermal expansions measured by the extensometers were compared to make sure there was no slippage or false readings during testing.

Due to much more compact design of the new heaters, the total length of the specimen was reduced to $177.8 \mathrm{~mm}$ (7in). The Alloy 617 test specimens were manufactured from the same plate, Heat 314626 from ThyssenKrupp VDM USA, Inc., with the longitudinal direction parallel to the rolling direction of the plate, as previously reported by Wang et al. (2013) (2014). Chemical compositions of the plate are shown in Table 1. The SS316H round bar material with nominal diameter of 1 in was purchased from Outokumpu Stainless Bar, LLC. The heat number is 101076 and the as-received SS316H bar satisfies specification ASME SA497. The chemical composition of the SS316H is listed in Table 2. The microstructure of the cross-sectional plane for the SS316H is shown in Fig. 3 (only near center about 0.5 in diameter is shown). Bi-modal grain size distribution with the grain sizes of $\sim 50 \mathrm{um}$ and $300 \mathrm{um}$ was observed.

The gage section of the test specimens is the same as the preceding work; with a gage length of 19.05 $\mathrm{mm}(0.75 \mathrm{in})$ and diameter of $6.35 \mathrm{~mm}(0.25 \mathrm{in})$. A drawing of the specimen geometry is shown in Fig. 4 . 


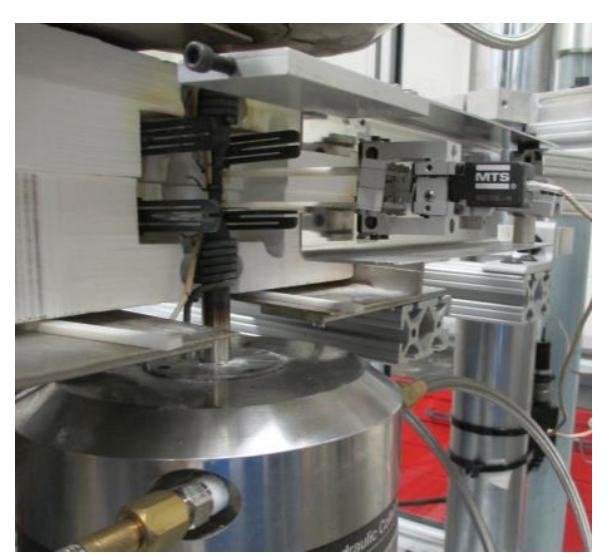

Fig. 2. Experimental setup with the igniter heater

Table 1. Chemical composition of Alloy 617 plate with heat number 314626 (weight \%)

\begin{tabular}{c|c|c|c|c|c|c|c|c|c|c|c|c}
\hline $\mathbf{C}$ & $\mathbf{S}$ & $\mathbf{C r}$ & $\mathbf{N i}$ & $\mathbf{M n}$ & $\mathbf{S i}$ & $\mathbf{M o}$ & $\mathbf{T i}$ & $\mathbf{C u}$ & $\mathbf{F e}$ & $\mathbf{A l}$ & $\mathbf{C o}$ & $\mathbf{B}$ \\
\hline 0.05 & $<0.002$ & 22.2 & $\mathrm{R} 54.1$ & 0.1 & 0.1 & 8.6 & 0.4 & 0.04 & 1.6 & 1.1 & 11.6 & $<0.001$ \\
\hline
\end{tabular}

Table 2. Chemical compositions of SS316H bar with heat number 101076 (weight \%)

\begin{tabular}{c|c|c|c|c|c|c|c|c|c|c}
\hline $\mathbf{C}$ & $\mathbf{P}$ & $\mathbf{S i}$ & $\mathbf{N i}$ & $\mathbf{M n}$ & $\mathbf{N}$ & $\mathbf{T i}$ & $\mathbf{S n}$ & $\mathbf{V}$ & $\mathbf{F e}$ & $\mathbf{C b}-\mathbf{T a}$ \\
\hline 0.045 & 0.028 & 0.650 & 10.120 & 1.420 & 0.053 & 0.002 & 0.006 & 0.060 & balance & 0.014 \\
\hline $\mathbf{S}$ & $\mathbf{C r}$ & $\mathbf{C o}$ & $\mathbf{M o}$ & $\mathbf{C b}$ & $\mathbf{A l}$ & $\mathbf{B}$ & & & & \\
\hline 0.024 & 16.230 & 0.279 & 2.090 & 0.014 & 0.004 & 0.004 & & & & \\
\hline
\end{tabular}

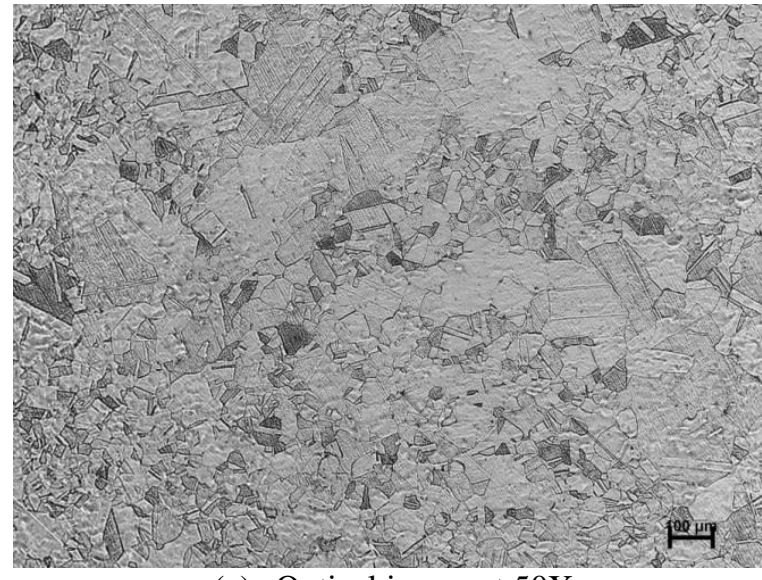

(a) Optical image at $50 \mathrm{X}$

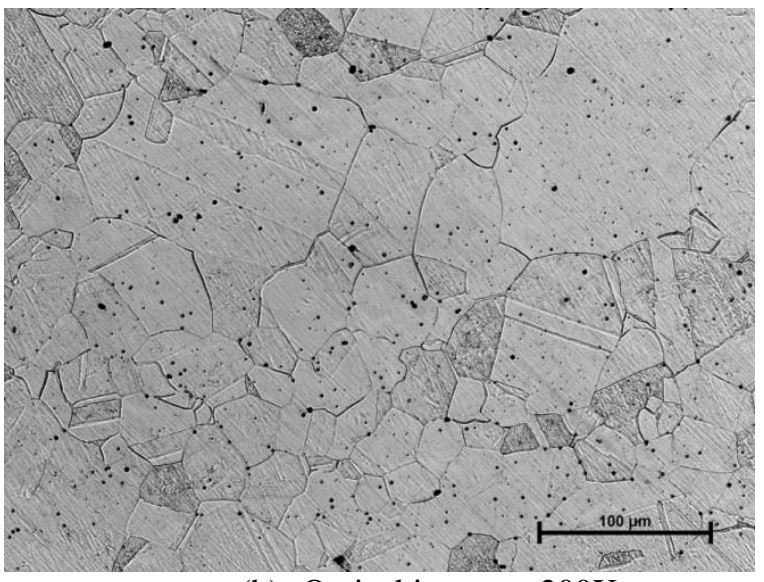

(b) Optical image at $200 \mathrm{X}$

Fig. 3. Optical images of the as-received SS316H. 


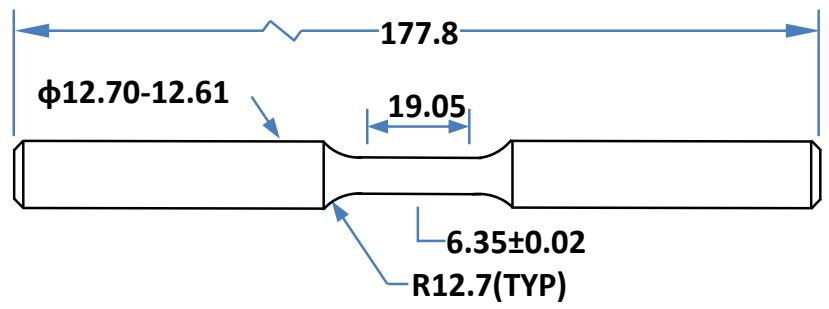

Fig. 4. Specimen geometry of Alloy 617 and SS316H used in two-bar thermal ratcheting experiments. Units are in $\mathbf{m m}$.

Fig. 5 shows the temperature versus time profiles used in this study. The time delay on the cooling segment was used in this phase of the study.

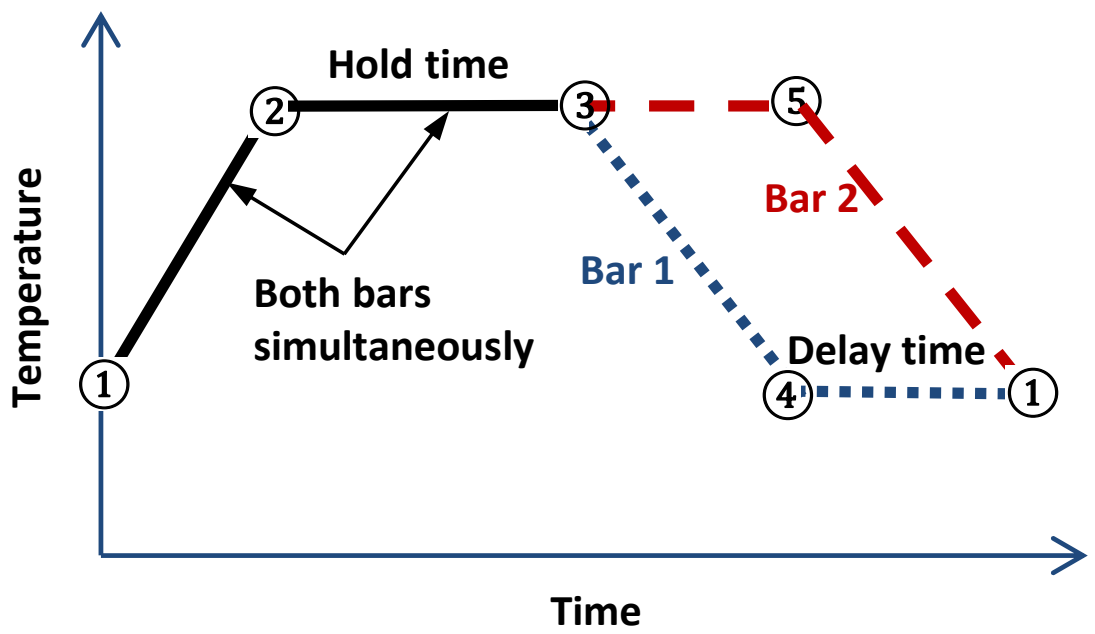

Fig. 5. Temperature vs. time histogram for two-bar thermal ratcheting experiments

Consistent with the preceding work by Wang et al. $(2013,2014)$, the ratcheting strain is defined as the difference in the mechanical strain at a time point in a cycle and that at the same time point in the reference cycle. The mechanical strain is the sum of the elastic strain and inelastic strain, and it can be extracted from the test data by subtracting the thermal expansion from the total strain. When the same reference point in the thermal cycle is selected, the amount of ratcheting strain calculated based on the total strain is the same as that calculated based on mechanical strain. In this study, the ratcheting strains were calculated from the maximum total strains of each cycle, and they were approximately the same values when calculated based on the minimum strains. It was observed that the cyclic ratcheting rates were approximately constant and the shape of the hysteresis loops were uniform for all the tests conducted. Thus, results from shorter test periods were extrapolated to obtain the ratcheting strain at $200 \mathrm{hr}$ to provide information to our parallel theoretical studies on strain limits.

Past experience shows that the first several cycles from one testing condition to another is significantly different and therefore is ignored in the ratcheting strain extrapolations. A reference cycle is used for each test and the test parameters and minimum strains of the reference cycles for all the testing conditions are summarized in this report. The previous results reported by Wang et.al. (2014) are also 
listed in Table 3. The ratcheting behavior is steady and the ratcheting rate is near constant from the reference cycle forward. Experiments with the same set of specimens were labeled in sequential test number. For example, test T17-1, T17-2, T17-3 and T17-7 were sequential tests on the same two sets of Alloy 617 specimens.

Table 3. Summary of prior two-bar thermal ratcheting experiments on Alloy 617 for temperature range of $650^{\circ} \mathrm{C}$ to $950^{\circ} \mathrm{C}$

\begin{tabular}{|c|c|c|c|c|c|c|c|c|c|}
\hline Test No. & $T 16$ & $T 17-1$ & $T 17-2$ & $T 17-3$ & $T 17-7$ & $T 18-5$ & $T 18-6$ & $T 18-7$ & $T 18-9$ \\
\hline $\begin{array}{l}\text { Applied mean } \\
\text { stress, } \mathrm{MPa}\end{array}$ & $\begin{array}{l}8.1 \\
\pm 1.5\end{array}$ & $\begin{array}{l}8.1 \\
\pm 1.5\end{array}$ & $\begin{array}{l}7.8 \\
\pm 1.5\end{array}$ & $\begin{array}{l}7.8 \\
\pm 1.5\end{array}$ & $\begin{array}{l}4.2 \\
\pm 1.5\end{array}$ & $\begin{array}{l}15.5 \\
\pm 1.8\end{array}$ & $\begin{array}{r}19.5 \\
\pm 1.5\end{array}$ & $\begin{array}{l}23.0 \\
\pm 1.5\end{array}$ & $\begin{array}{l}4.6 \\
\pm 1.5\end{array}$ \\
\hline Time delay, min & 1 & 10 & 5 & 3 & 10 & 10 & 1 & 2 & 60 \\
\hline $\begin{array}{l}\text { Total No. of } \\
\text { cycles tested }\end{array}$ & 138 & 15 & 17 & 34 & 24 & 15 & 16 & 15 & 18 \\
\hline $\begin{array}{l}\text { Ratcheting rate } \\
\text { (per cycle), } \%\end{array}$ & 0.005 & -0.067 & -0.008 & 0.00001 & $\begin{array}{l}- \\
0.099\end{array}$ & -0.01 & 0.004 & 0.017 & \begin{tabular}{|l|}
-0.08 \\
\end{tabular} \\
\hline $\begin{array}{l}\text { Initial stress on } \\
\text { Bar } 1, \mathrm{MPa}\end{array}$ & 8.2 & 6,9 & -212.1 & -183.5 & $\begin{array}{l}- \\
180.5\end{array}$ & 210.3 & -140 & -111.6 & -20.8 \\
\hline $\begin{array}{l}\text { Initial stress on } \\
\text { Bar 2, MPa }\end{array}$ & 9.1 & 8.4 & 224.8 & 197.7 & 190.6 & -177 & 178 & 156.6 & 28.6 \\
\hline $\begin{array}{l}\text { Initial residual } \\
\text { total strain, \% }\end{array}$ & 0 & 0 & -1.6 & -1.18 & $\begin{array}{l}-0.96 \\
\end{array}$ & $\begin{array}{l}-0.29 \\
\end{array}$ & -0.45 & -0.36 & $\begin{array}{l}-0.5 \\
\end{array}$ \\
\hline $\begin{array}{l}\text { Reference cycle } \\
\text { No. }\end{array}$ & 1 & 1 & 2 & 2 & 2 & 2 & 2 & 2 & 2 \\
\hline $\begin{array}{l}\text { Min. strain of } \\
\text { the reference } \\
\text { cycle, } \%\end{array}$ & -0.0017 & -0.14 & -0.48 & -1.14 & -1.29 & -0.33 & -0.43 & -0.33 & -0.8 \\
\hline $\begin{array}{l}\text { Stress range per } \\
\text { cycle for Bar } 1 \text {, } \\
\mathrm{MPa}\end{array}$ & $\begin{array}{l}70.7 \\
\pm 1.3\end{array}$ & $\begin{array}{l}310.8 \\
\pm 3.1\end{array}$ & $\begin{array}{l}268.5 \\
\pm 1.7\end{array}$ & $\begin{array}{l}184.2 \\
\pm 2.5\end{array}$ & $\begin{array}{l}306.4 \\
\pm 5.1\end{array}$ & $\begin{array}{l}300 \\
\pm 2.8\end{array}$ & $\begin{array}{l}299.8 \\
\pm 3.0\end{array}$ & $\begin{array}{l}302.4 \\
\pm 2.4\end{array}$ & $\begin{array}{l}284.8 \\
\pm 5.5\end{array}$ \\
\hline $\begin{array}{l}\text { Stress range per } \\
\text { cycle for Bar } 1 \text {, } \\
\text { MPa }\end{array}$ & $\begin{array}{l}67.3 \\
\pm 1.2\end{array}$ & $\begin{array}{l}305.9 \\
\pm 2.5\end{array}$ & $\begin{array}{l}264.8 \\
\pm 1.5\end{array}$ & $\begin{array}{l}180.6 \\
\pm 2.6\end{array}$ & $\begin{array}{l}301.5 \\
\pm 5.6\end{array}$ & $\begin{array}{l}297.7 \\
\pm 2.5\end{array}$ & $\begin{array}{l}297.4 \\
\pm 2.8\end{array}$ & $\begin{array}{l}300.7 \\
\pm 2.4\end{array}$ & $\begin{array}{l}283.3 \\
\pm 5.6\end{array}$ \\
\hline
\end{tabular}

These test results showed an anomaly when compared to strain limit predictions based on the E- PP strain limits code case.

Fig. 6 is a plot of two-bar extrapolated test data compared with two methods for predicting allowable loading that would result in $1 \%$ or less creep strain. The vertical axis is the time delay from point 3 on Fig. 5, the initiation of the thermal down ramp in bar 1, and point 5, the initiation of the thermal down ramp in bar 2 . The total temperature change and ramp rates are the same for the tests shown, $300^{\circ} \mathrm{C}$ and $30^{\circ} \mathrm{C} / \mathrm{min}$ respectively. The variables are the nominal applied load and the delay time, or thermal stress, in the bars. A shorter delay time results in a lower thermal stress and the maximum delay time, 10min, maximizes the thermal stress. 


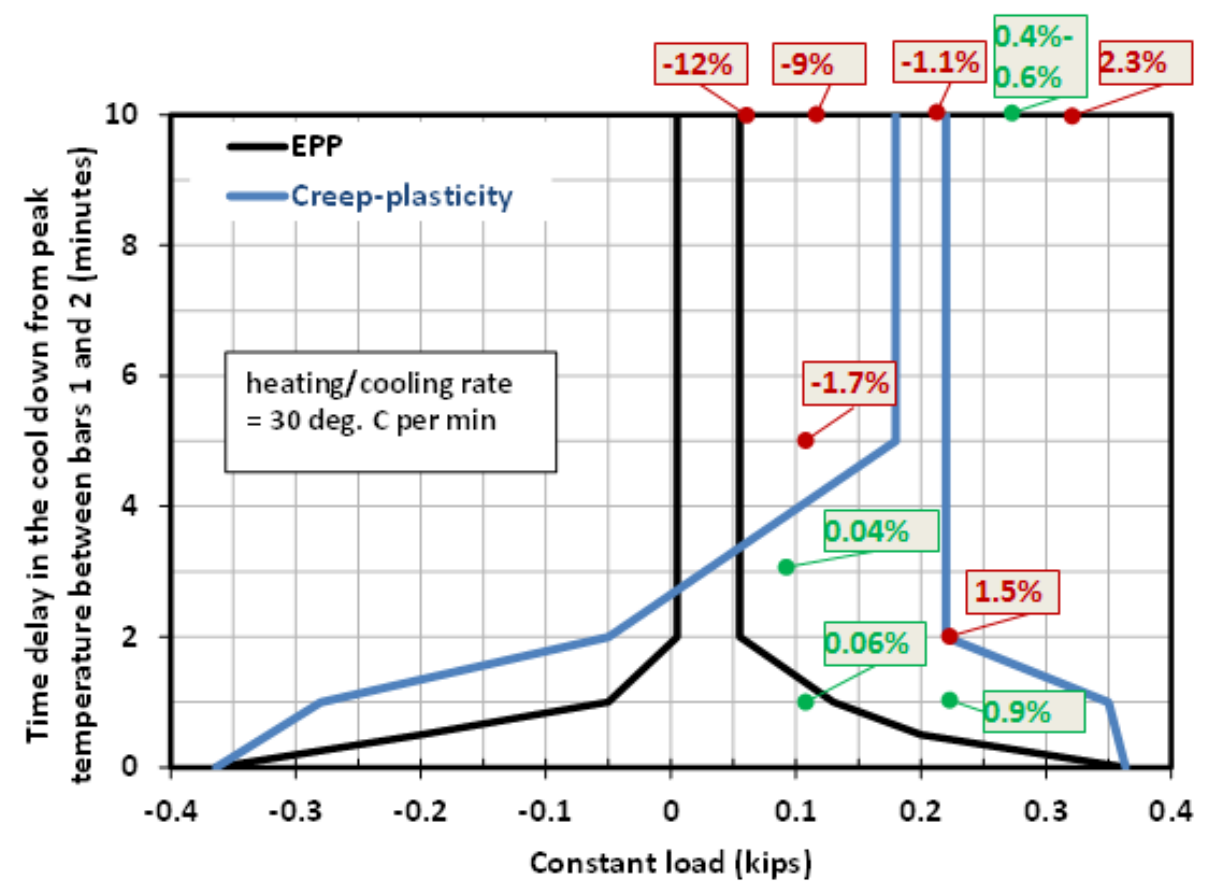

Fig. 6. Two bar test data with $1 \%$ design envelope predictions from the strain limits code case and inelastic analysis (Alloy 617 with testing temperature range of $650^{\circ} \mathrm{C}$ to $950^{\circ} \mathrm{C}$ )

The allowable load combinations resulting in less than or equal to $1 \%$ strain shown on Fig. 6 are based on the E-PP methodology in the strain limits code case on the left side and inelastic analysis on the right. In both cases, the limits have a stovepipe appearance with a narrow range of sustained loading effectively balancing an enhanced deformation proportional to the applied cyclic thermal stress. However, in the case of the E-PP prediction, the axis of the stove pipe occurs at a mean load that is too low compared to the experimental results. At a 10min time delay, the projected strain accumulation is about $12 \%$ in compression with a tensile load of 50lb. On the other hand, the inelastic analysis stove pipe roughly centered at 200lb nominal load is in fair, but much better, agreement with the measured compressive strain of $1.1 \%$ at a $10 \mathrm{~min}$ delay.

Although the $10 \mathrm{~min}$ delay results with a $300^{\circ} \mathrm{C}$ temperature difference would represent an unrealistically extreme through wall thermal gradient for an actual component, it illustrates the potentially unconservative results from the E-PP model when applied to skeletal structures for some loading conditions, e.g. relatively low nominal load; and overly conservative results for other conditions, e.g. higher nominal load.

In response to this observation it was postulated that there are limitations on the ability of a two bar model to represent more prototypic real structures which have continuously varying geometry and load as opposed to the discontinuous step changes associated with the two bar configuration. This conclusion was assessed by a simplified inelastic analysis of a Bree type model, using the same inelastic analysis model that showed agreement with the two-bar experimental results, to compare with predictions from the E-PP strain limits code case (Jetter et.al., 2015). In the Bree type model a pressurized pipe is required to survive thermal cycles for 200 hours without violating a $1 \%$ inelastic strain limit. In this case, the strain limit refers to the hoop strain in the center of the pipe wall. This reflects the requirement for a $1 \%$ inelastic strain limit on average or membrane strain. The E-PP analysis method is used to determine acceptable pressures (negative and positive) for which the $1 \%$ inelastic strain limit is satisfied. These design 
calculations are then compared to the results of a detailed cyclic inelastic analysis.

Fig. 7 is a summary of all load cases with stress normalized by the mean wall temperature yield stress at the maximum thermal stress (Jetter et.al., 2015). The usual Bree diagram limits for ratcheting and shakedown are shown to indicate regions of behavior. It may be seen that that all the inelastic calculations with lives of $200-300$ hours are less conservative than the E-PP design calculations, but not excessively so; thus the E-PP methodology may be concluded to provide a reasonable design bound for the response of representative structures with distributed properties and temporal and spatially varying structural response.

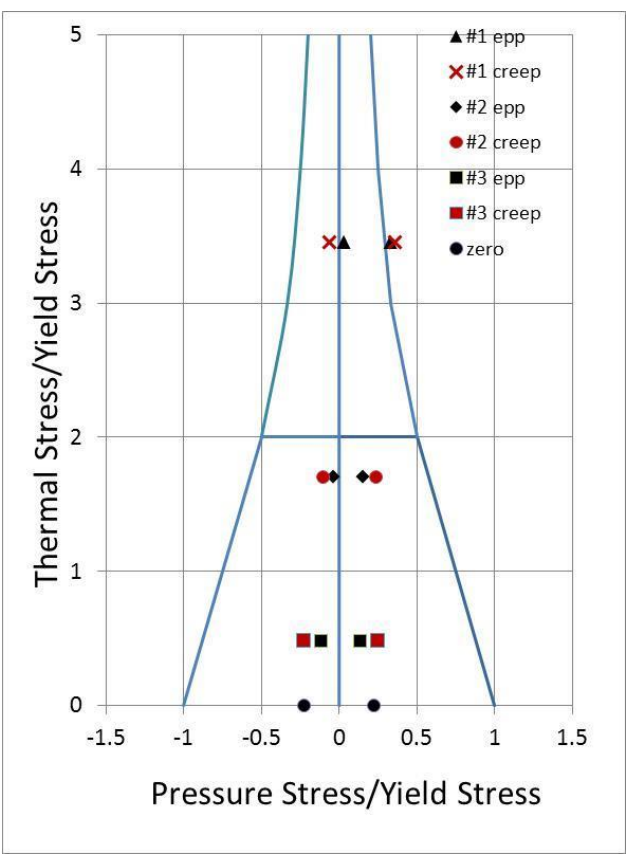

Fig. 7. Summary of E-PP and Creep Analysis Load Cases on Bree Plot of Normalized Primary and Thermal Stress

To reinforce the above conclusion and to provide a direct link back to the two-bar test results, an additional, more severe, thermal load case for the pipe geometry was evaluated, again by comparing the result of an E-PP evaluation to inelastic analysis results. The bore and OD cyclic temperatures were similar to those used in the two-bar ratcheting tests. Steady state temperature distributions in the wall are assumed. Internal pressure is the design variable, which is constant over the cycles. E-PP analyses are performed to obtain design pressures which satisfy the $1 \%$ inelastic strain criterion. Creep analyses were performed to obtain as realistic predictions as possible with current data. The following conclusions may be drawn with respect to the response of the Bree type cylinder to the more severe two-bar test type transients:

- The E-PP analyses indicate that acceptable design pressures, which satisfy the zero- ratcheting criterion, do not exist for this problem.

- The inelastic analyses of a limited number of cycles indicate that pressures between zero and 300 psi produce strain rates, which when extrapolated to 200 hours, imply inelastic strains in the center of the pipe wall less than $1 \%$.

- The conservatism of the E-PP analysis is therefore demonstrated 


\section{CURRENT TWO-BAR THERMAL RACHETING TEST RESULTS}

The two-bar tests discussed herein are part of an ongoing series of tests with cyclic loading at high temperatures using specimens representing key features of potential component designs. The initial focus of the two-bar ratcheting test program, to verify the procedure for evaluation of strain limits for Alloy 617 at very high temperatures, was reported previously, Wang et.al. (2014). The current program has been expanded to respond to guidance from ASME Code committees that the proposed EPP methodology should also apply to other Subsection NH materials throughout their allowed temperature range. To support these objectives, two suites of tests have been accomplished during this reporting period. One suite address the issue of the response of Alloy 617 at the lower temperature ranges $\left(500-800^{\circ} \mathrm{C}\right)$ and $\left(350-650^{\circ} \mathrm{C}\right)$ as previously discussed by Wang et.al. (2014). The other suite addresses the response of $316 \mathrm{SS}$ up to its current maximum allowed temperature of $1500^{\circ} \mathrm{F}\left(815^{\circ} \mathrm{C}\right)$.

\subsection{ALLOY 617 TWO-BAR TEST RESULTS}

Two-bar thermal ratcheting tests were performed on Alloy 617 to assess the material response to cyclic thermal loading under two-bar testing conditions at a lower total temperature range of $500-800^{\circ} \mathrm{C}$ and for a limited number of test conditions at $350-650^{\circ} \mathrm{C}$. The results for the $500-800^{\circ} \mathrm{C}$ temperature range are shown in Table 4.

\subsubsection{0-800 ${ }^{\circ} \mathrm{C}$ Results}

The results for the $500-800^{\circ} \mathrm{C}$ temperature range are shown in the following table.

Table 4. Summary of two-bar thermal ratcheting experiments on Alloy 617 for temperature range of $500-800^{\circ} \mathrm{C}$

\begin{tabular}{l|l|l|l|l|l|l|l|l}
\hline Test No. & T20-6 & T20-7 & T20-8 & T20-9 & T20-10 & T20-11 & T20-12 & T20-13 \\
\hline $\begin{array}{l}\text { Actual average total load } \\
\text { (lbs) }\end{array}$ & -400 & 456.5 & 731.3 & 730.2 & 70.3 & 120.9 & 120 & 80 \\
\hline Nominal total load (lbs) & -425 & 425 & 700 & 700 & 50 & 100 & 100 & 50 \\
\hline Applied mean stress, MPa & $\begin{array}{l}-28.3 \\
\pm 0.75\end{array}$ & $\begin{array}{l}32.32 \\
\pm 0.78\end{array}$ & $\begin{array}{l}51.8 \\
\pm 0.75\end{array}$ & $\begin{array}{l}51.7 \\
\pm 0.80\end{array}$ & $\begin{array}{l}5.00 \\
\pm 0.70\end{array}$ & $\begin{array}{l}8.56 \\
\pm 0.71\end{array}$ & $\begin{array}{l}8.49 \\
\pm 0.73\end{array}$ & $\begin{array}{l}5.66 \\
\pm 0.69\end{array}$ \\
\hline Time delay, min & 10 & 10 & 5 & 10 & 5 & 5 & 10 & 2 \\
\hline Total No. of cycles tested & 16 & 28 & 47 & 20 & 21 & 15 & 33 & 49 \\
\hline $\begin{array}{l}\text { Ratcheting rate (per } \\
\text { cycle), \% }\end{array}$ & -0.143 & 0 & 0.0008 & 0.0028 & 0 & 0 & -0.0034 & 0 \\
\hline $\begin{array}{l}\text { Initial stress on Bar 1, } \\
\text { MPa }\end{array}$ & -214.3 & -230.8 & -185.3 & -188.7 & -77.1 & -99.7 & -107.2 & -274.2 \\
\hline $\begin{array}{l}\text { Initial stress on Bar 2, } \\
\text { MPa }\end{array}$ & 155.14 & 293.1 & 285.3 & 289.3 & 87.3 & 116.5 & 123.7 & 283.3 \\
\hline $\begin{array}{l}\text { Initial residual total strain, } \\
\%\end{array}$ & 0.09 & -2.34 & -2.17 & -2.27 & -2.06 & -2.11 & -2.11 & -2.34 \\
\hline Reference cycle No. & 5 & 5 & 5 & 5 & 5 & 5 & 5 & 5 \\
\hline $\begin{array}{l}\text { Min. strain of the } \\
\text { reference cycle, \% }\end{array}$ & -0.92 & -2.25 & -2.02 & -2.16 & -2.05 & -2.06 & -2.2 & -2.18 \\
\hline $\begin{array}{l}\text { Stress range per cycle for } \\
\text { Bar 1, MPa }\end{array}$ & $\begin{array}{l}470.8 \\
\pm 12.2\end{array}$ & $\begin{array}{l}480.7 \\
\pm 3.3\end{array}$ & $\begin{array}{l}284.2 \\
\pm 1.77\end{array}$ & $\begin{array}{l}474.7 \\
\pm 0.66\end{array}$ & $\begin{array}{l}285.5 \\
\pm 1.97\end{array}$ & $\begin{array}{l}284 \\
\pm 1.55\end{array}$ & $\begin{array}{l}471.4 \\
\pm 0.79\end{array}$ & $\begin{array}{l}122.5 \\
\pm 1.4\end{array}$ \\
\hline $\begin{array}{l}\text { Stress range per cycle for } \\
\text { Bar 2, MPa }\end{array}$ & $\begin{array}{l}464.9 \\
\pm 11.9\end{array}$ & $\begin{array}{l}474.8 \\
\pm 3.2\end{array}$ & $\begin{array}{l}280 \\
\pm 1.88\end{array}$ & $\begin{array}{l}468.7 \\
\pm 0.83\end{array}$ & $\begin{array}{l}281.5 \\
\pm 1.65\end{array}$ & $\begin{array}{l}279.6 \\
\pm 1.7\end{array}$ & $\begin{array}{l}464.9 \\
\pm 0.65\end{array}$ & $\begin{array}{l}115 \\
\pm 1.45\end{array}$ \\
\hline
\end{tabular}


Table 4--continue

\begin{tabular}{|c|c|c|c|c|c|c|c|c|c|}
\hline Test No. & $T 20-14$ & $T 20-15$ & $T 20-16$ & T20-17 & T20-18 & $T 22-1$ & $T 22-2$ & $T 22-3$ & $T 22-4$ \\
\hline $\begin{array}{l}\text { Actual average } \\
\text { total load (lbs) }\end{array}$ & 66.7 & 1521.1 & -402.5 & -413.8 & 1516.5 & 630 & 321.2 & 225.7 & 124.1 \\
\hline $\begin{array}{l}\text { Nominal total } \\
\text { load (lbs) }\end{array}$ & 50 & 1500 & -425 & -425 & 1500 & 600 & 300 & 200 & 100 \\
\hline $\begin{array}{l}\text { Applied mean } \\
\text { stress, } \mathrm{MPa}\end{array}$ & $\begin{array}{l}4.72 \\
\pm 0.62\end{array}$ & $\begin{array}{l}107.7 \\
\pm 0.73\end{array}$ & $\begin{array}{l}-28.5 \\
\pm 0.63\end{array}$ & $\begin{array}{l}-29.3 \\
\pm 0.6\end{array}$ & $\begin{array}{l}107.4 \\
\pm 0.58\end{array}$ & $\begin{array}{l}44.6 \\
\pm 0.9\end{array}$ & $\begin{array}{l}22.7 \\
\pm 0.8\end{array}$ & $\begin{array}{l}16.0 \\
\pm 0.8\end{array}$ & $\begin{array}{l}8.8 \\
\pm 0.76\end{array}$ \\
\hline Time delay, min & 1 & 10 & 5 & 2 & 5 & 10 & 10 & 10 & 10 \\
\hline $\begin{array}{l}\text { Total No. of } \\
\text { cycles tested }\end{array}$ & 35 & 22 & 33 & 34 & 17 & 32 & 68 & 53 & 48 \\
\hline $\begin{array}{l}\text { Ratcheting rate } \\
\text { (per cycle), \% }\end{array}$ & $\begin{array}{ll}\sim 0 \\
\end{array}$ & 0.357 & -0.015 & 0.169 & 0.183 & 0.014 & -0.002 & -0.005 & -0.014 \\
\hline $\begin{array}{l}\text { Initial stress on } \\
\text { Bar } 1, \mathrm{MPa}\end{array}$ & -66.2 & 51.4 & -197 & -158.1 & 46.7 & 40.9 & $\begin{array}{l}-195.8 \\
\end{array}$ & -228.3 & -241.8 \\
\hline $\begin{array}{l}\text { Initial stress on } \\
\text { Bar 2, MPa }\end{array}$ & $\begin{array}{l}75.8 \\
\end{array}$ & 165 & 138 & 97.93 & 169.5 & 47.2 & 239.8 & 256.1 & 257.6 \\
\hline $\begin{array}{l}\text { Initial residual } \\
\text { total strain, \% }\end{array}$ & -2.17 & -2.12 & 5.63 & 4.96 & 5.0 & 0 & 0.763 & 0.572 & 0.388 \\
\hline $\begin{array}{l}\text { Reference cycle } \\
\text { No. }\end{array}$ & 5 & 5 & 5 & 5 & 5 & 9 & 9 & 9 & 9 \\
\hline $\begin{array}{l}\text { Min. strain of } \\
\text { the reference } \\
\text { cycle, } \%\end{array}$ & -2.17 & -0.63 & 5.39 & 4.97 & 6.0 & 0.389 & 0.669 & 0.521 & 0.242 \\
\hline $\begin{array}{l}\text { Stress range per } \\
\text { cycle for Bar } 1 \text {, } \\
\mathrm{MPa}\end{array}$ & $\begin{array}{l}65.5 \\
\pm 4.14\end{array}$ & $\begin{array}{l}418.4 \\
\pm 4.02\end{array}$ & $\begin{array}{l}270.5 \\
\pm 6.45\end{array}$ & $\begin{array}{l}108.6 \\
\pm 1.57\end{array}$ & $\begin{array}{l}252.8 \\
\pm 3.1\end{array}$ & $\begin{array}{l}442 \\
\pm 1.8\end{array}$ & $\begin{array}{l}447.7 \\
\pm 1.4\end{array}$ & $\begin{array}{l}447.6 \\
\pm 1.1\end{array}$ & $\begin{array}{l}452 \\
\pm 1.8\end{array}$ \\
\hline $\begin{array}{l}\text { Stress range per } \\
\text { cycle for Bar } 2 \text {, } \\
\text { MPa }\end{array}$ & $\begin{array}{l}63.3 \\
\pm 4.1\end{array}$ & $\begin{array}{l}413.4 \\
\pm 3.63\end{array}$ & $\begin{array}{l}267.1 \\
\pm 6.44\end{array}$ & $\begin{array}{l}106.8 \\
\pm 10.5\end{array}$ & $\begin{array}{l}250.8 \\
\pm 3.1\end{array}$ & $\begin{array}{l}437.2 \\
\pm 1.4\end{array}$ & $\begin{array}{l}443 \\
\pm 1.3\end{array}$ & $\begin{array}{l}443 \\
\pm 0.5\end{array}$ & $\begin{array}{l}447.4 \\
\pm 1.4\end{array}$ \\
\hline
\end{tabular}

Table 4-continue

\begin{tabular}{l|l|l|l|l|l|l|l}
\hline Test No. & T22-5 & T22-6 & T22-7 & T22-8 & T22-9 & T22-10 & T22-11 \\
\hline Actual average total load (lbs) & 123.6 & 117.9 & 115.8 & 724.8 & -30.3 & -83.2 & 719.7 \\
\hline Nominal total load (lbs) & 100 & 100 & 100 & 700 & -50 & -100 & 700 \\
\hline Applied mean stress, MPa & 8.8 & 8.3 & 8.2 & 51.3 & -2.14 & -5.89 & 51.0 \\
& \pm 0.8 & \pm 0.8 & \pm 0.8 & \pm 0.8 & \pm 0.76 & \pm 0.75 & \pm 0.76 \\
\hline Time delay, min & 3 & 5 & 8 & 10 & 5 & 5 & 5 \\
\hline Total No. of cycles tested & 32 & 32 & 35 & 43 & 36 & 33 & 35 \\
\hline Ratcheting rate (per cycle), \% & $\sim 0$ & $\sim 0$ & -0.005 & 0.046 & -0.0016 & -0.0018 & 0.0087 \\
\hline Initial stress on Bar 1, MPa & -252.7 & -51.8 & -97.5 & -150.5 & -200.9 & -105.9 & -56.4 \\
\hline Initial stress on Bar 2, MPa & 270.2 & 68.3 & 114.8 & 254.9 & 195.9 & 93.8 & 155.3 \\
\hline Initial residual total strain, \% & -0.090 & -0.001 & -0.028 & -0.291 & 1.644 & 1.548 & 1.482 \\
\hline Reference cycle No. & 9 & 9 & 9 & 9 & 9 & 9 & 9 \\
\hline Min. strain of the reference cycle, \% & 0.013 & -0.019 & -0.142 & -0.489 & 1.59 & 1.53 & 1.71 \\
\hline Stress range per cycle for Bar 1, MPa & 175.8 & 284.2 & 425.9 & 442.7 & 275.8 & 270 & 258.3 \\
& \pm 1.4 & \pm 2.4 & \pm 1.2 & \pm 1.5 & \pm 4.1 & \pm 1.9 & \pm 9.4 \\
\hline Stress range per cycle for Bar 2, MPa & 171.7 & 280.1 & 421 & 438.4 & 271.8 & 266.1 & 253.7 \\
& \pm 1.3 & \pm 1.8 & \pm 1.0 & \pm 1.5 & \pm 4.2 & \pm 1.9 & \pm 9.1 \\
\hline
\end{tabular}


Shown below in Fig. 8 is the extrapolated strain at $200 \mathrm{hr}$ for the $500-800^{\circ} \mathrm{C}$ temperature range as compared to the allowable load combinations resulting in less than or equal to $1 \%$ strain based on the EPP methodology in the strain limits code case. As can be seen, the agreement between the strain based on the test results is in good agreement with the 1\% limit predictions from the EPP based strain limit code case. This is a significant difference as compared to the results for the higher temperature range in Fig. 6 that were not in good agreement with the strain limit code case limits.

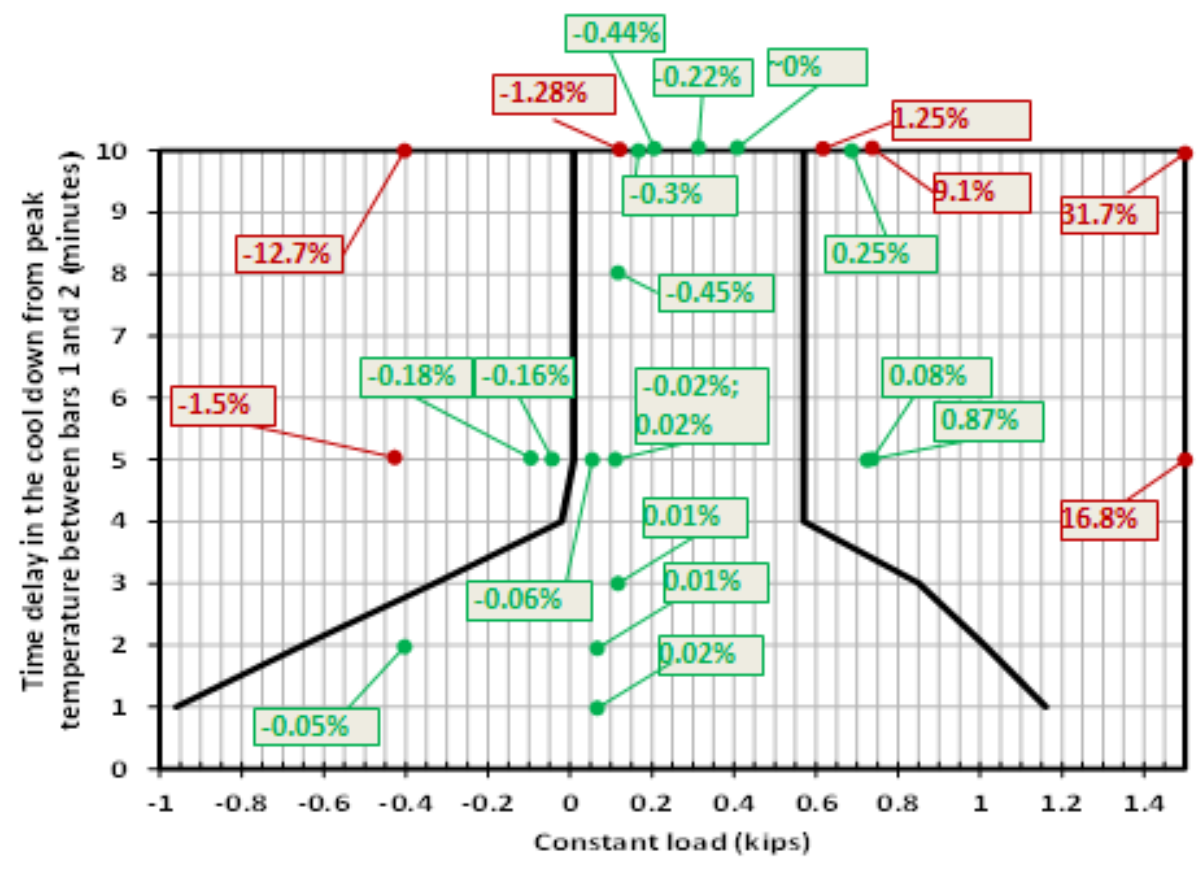

Fig. 8. Two bar test data with $1 \%$ design envelope predictions from the strain limits code case

(Alloy 617 with testing temperature range of $500^{\circ} \mathrm{C}$ to $800{ }^{\circ} \mathrm{C}$ )

Shown below in Fig. 9 and Fig. 10 are the hysteresis loops and stress time histories for a nominal load of $100 \mathrm{lb}$ and 10 minute time delay for both the $500-800^{\circ} \mathrm{C}$ and, for comparison, the $650-950^{\circ} \mathrm{C}$ temperature ranges. The labeled points on the plots correspond to the loading points shown on Fig. 5 with the time delay in the cooling cycle. 

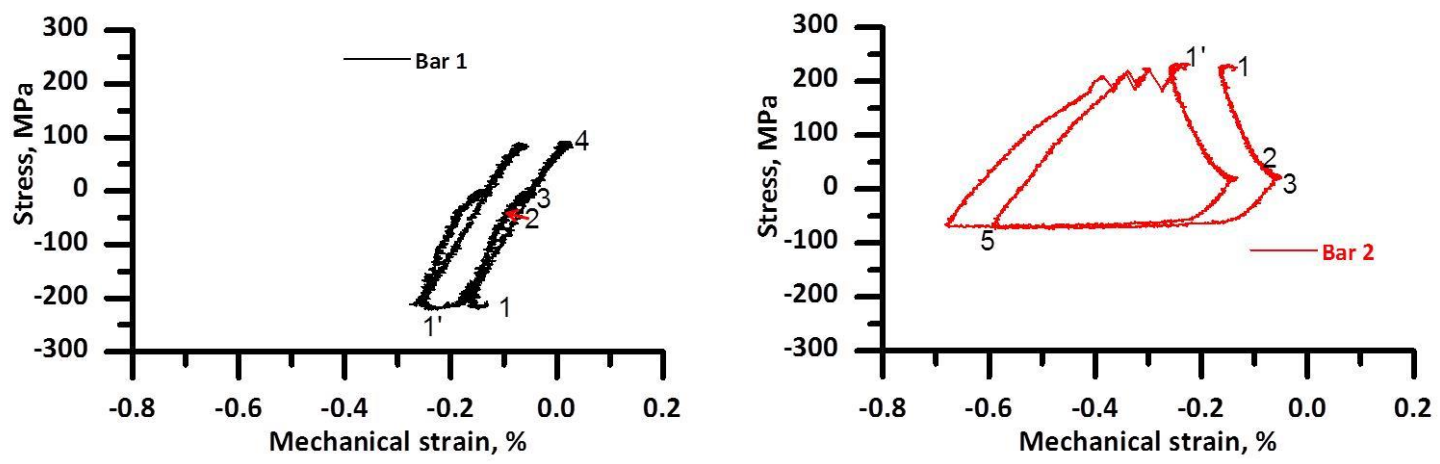

(a)
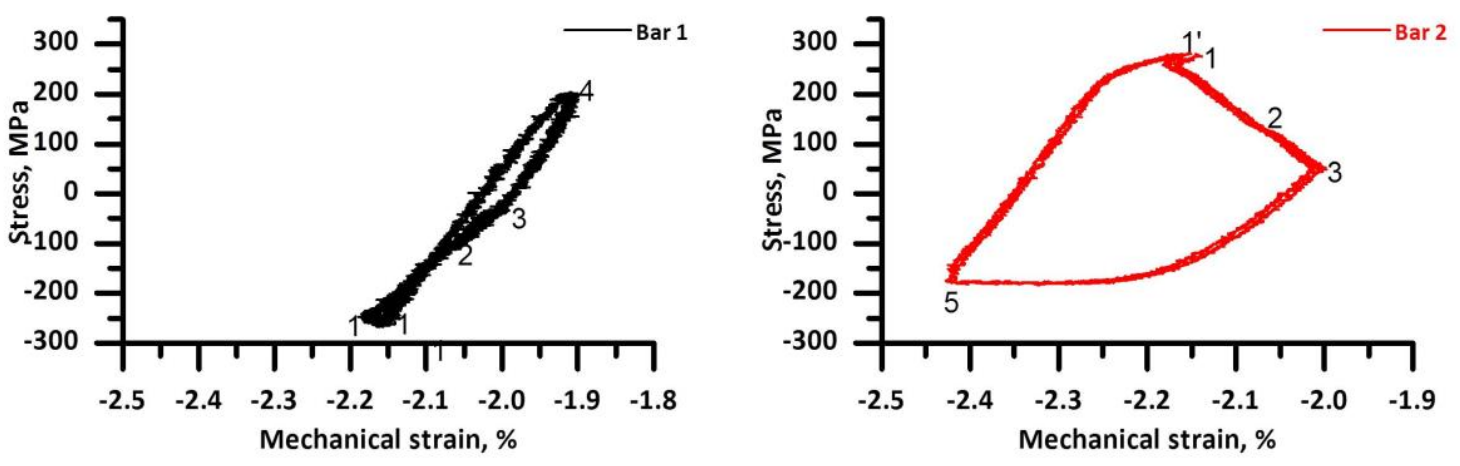

(b)

Fig. 9. Stress vs mechanical strain for Alloy 617 with nominal $100 \mathrm{lbs}$ total load and $10 \mathrm{~min}$ time delay for test T17-1 $\left(650^{\circ} \mathrm{C}\right.$ to $\left.950^{\circ} \mathrm{C}(\mathrm{a})\right)$ and test $\mathrm{T20}-12\left(500^{\circ} \mathrm{C}\right.$ to $\left.800^{\circ} \mathrm{C}(\mathrm{b})\right)$

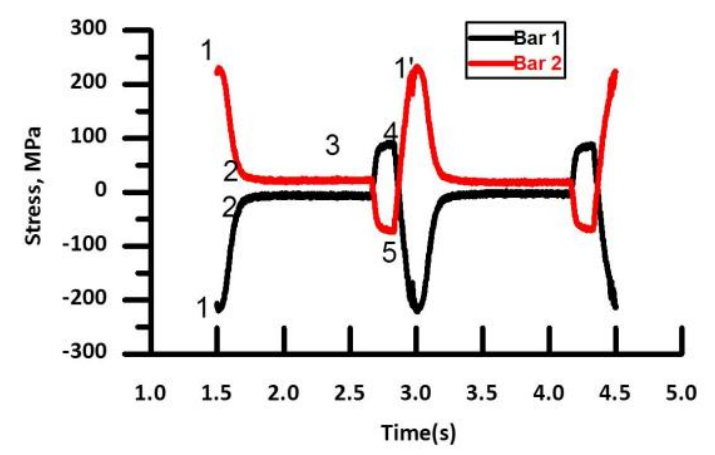

(a)

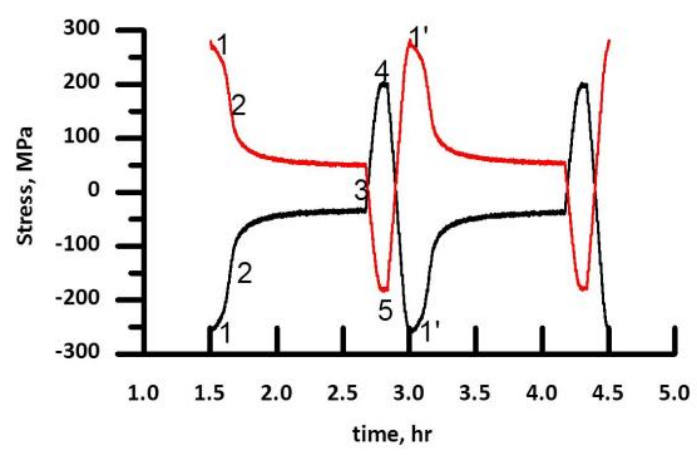

(b)

Fig. 10. Stress vs time for Alloy 617 with nominal 100lbs total load and $10 \mathrm{~min}$ time delay for test $\mathrm{T} 17-1\left(650^{\circ} \mathrm{C}\right.$ to $\left.950^{\circ} \mathrm{C}(\mathrm{a})\right)$ and test $\mathrm{T20}-12\left(500^{\circ} \mathrm{C}\right.$ to $\left.800^{\circ} \mathrm{C}(\mathrm{b})\right)$ 


\subsubsection{0-650 ${ }^{\circ} \mathrm{C}$ Results}

The results for the $350-650^{\circ} \mathrm{C}$ temperature range are shown in the following table.

Table 5. Summary of two-bar thermal ratcheting experiments on Alloy 617 for temperature range of $350-650^{\circ} \mathrm{C}$

\begin{tabular}{l|l|l|l|l|l}
\hline Test No. & $\mathbf{T 2 0 - 1}$ & $\mathbf{T 2 0 - 2}$ & $\mathbf{T 2 0 - 3}$ & $\mathbf{T 2 0 - 4}$ & $\mathbf{T 2 0 - 5}$ \\
\hline Actual average total load (lbs) & 70 & 170 & 320 & 721 & -407.2 \\
\hline Nominal total load (lbs) & 50 & 150 & 300 & 700 & -425 \\
\hline Applied mean stress, MPa & $4.8 \pm 1.0$ & $12 \pm 0.81$ & $22.7 \pm 0.82$ & $51.1 \pm 0.82$ & $-28.8 \pm 0.75$ \\
\hline Time delay, min & 10 & 10 & 10 & 10 & 10 \\
\hline Total No. of cycles tested & 47 & 20 & 32 & 16 & 47 \\
\hline Ratcheting rate (per cycle), \% & $\sim 0$ & $\sim 0$ & $\sim 0$ & $\sim 0$ & $\sim 0$ \\
\hline Initial stress on Bar 1, MPa & 0.25 & 214.3 & -193 & -164.4 & -241.2 \\
\hline Initial stress on Bar 2, MPa & 4.0 & -186 & 238 & 266.8 & 183.7 \\
\hline Initial residual total strain, \% & 0 & -0.05 & -0.047 & -0.046 & -0.082 \\
\hline Reference cycle No. & 10 & 10 & 10 & 10 & 10 \\
\hline Min. strain of the reference cycle, \% & -0.037 & -0.052 & -0.056 & -0.038 & -0.085 \\
\hline Stress range per cycle for Bar 1, MPa & $472.3 \pm 2.6$ & $475 \pm 1.38$ & $476 \pm 3.38$ & $478 \pm 3.9$ & $475 \pm 2.8$ \\
\hline Stress range per cycle for Bar 2, MPa & $465.9 \pm 2.6$ & $469 \pm 4.2$ & $470 \pm 3.0$ & $472 \pm 4.0$ & $468.5 \pm 2.62$ \\
\hline
\end{tabular}

The results tabulated above show no ratcheting at a 10min time delay for a range of applied load. Fig. 11 below, with the $1 \%$ strain limit design envelope from the strain limit code case is consistent with the test results. The spike in the allowable time delay at zero applied load indicates there is no ratcheting/incremental deformation without an applied load when creep effects are negligible. 


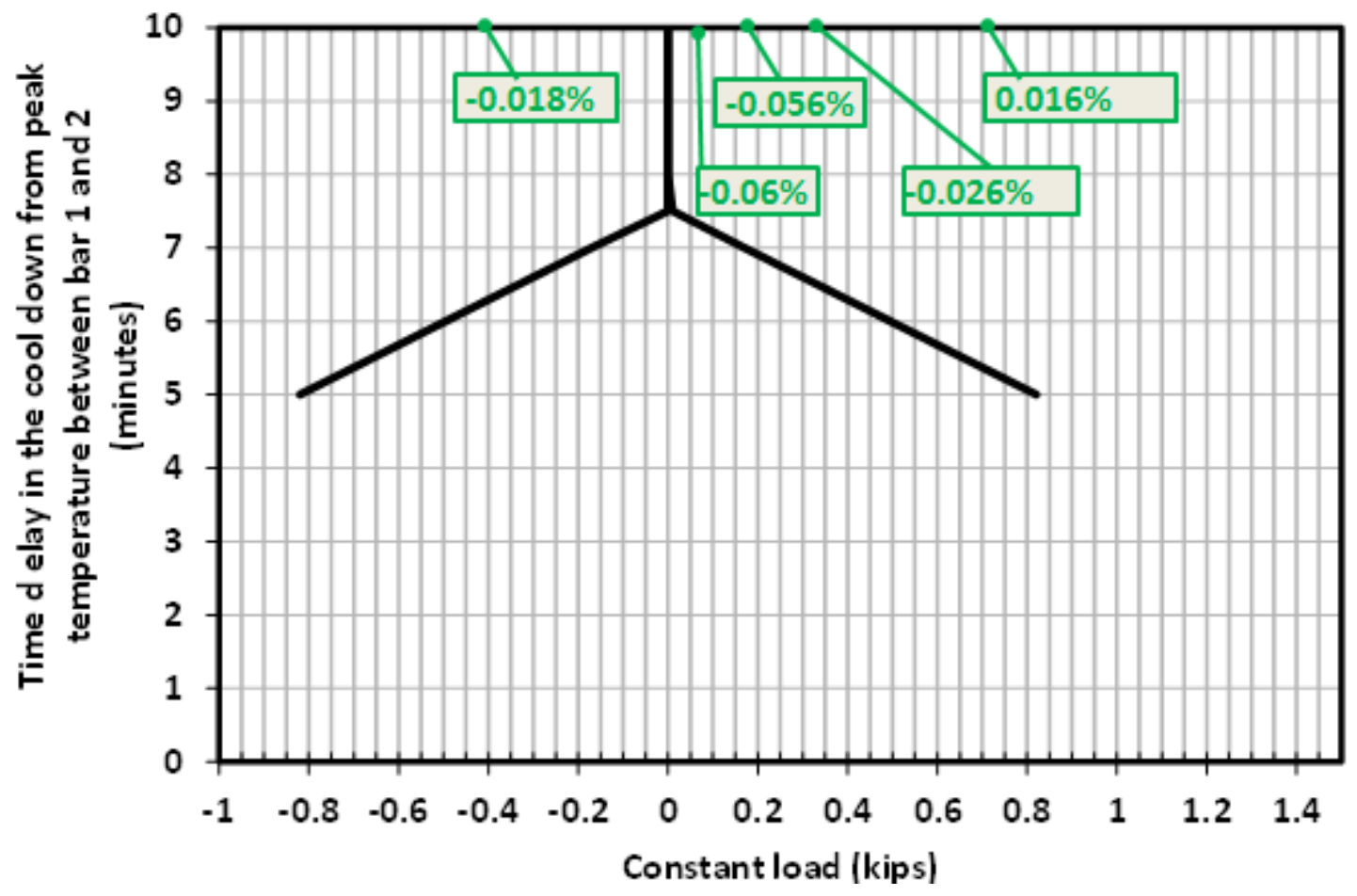

Fig. 11. Two bar test data with $1 \%$ design envelope predictions from the strain limits code case (Alloy 617 with testing temperature range of $350^{\circ} \mathrm{C}$ to $650^{\circ} \mathrm{C}$ )

Also shown is a stress time history, Fig. 12 , for the $350-650^{\circ} \mathrm{C}$ temperature range, also at a 10 minute time delay but for a nominal load of $150 \mathrm{lb}$. Fig. 13 shows the resultant hysteresis loops.

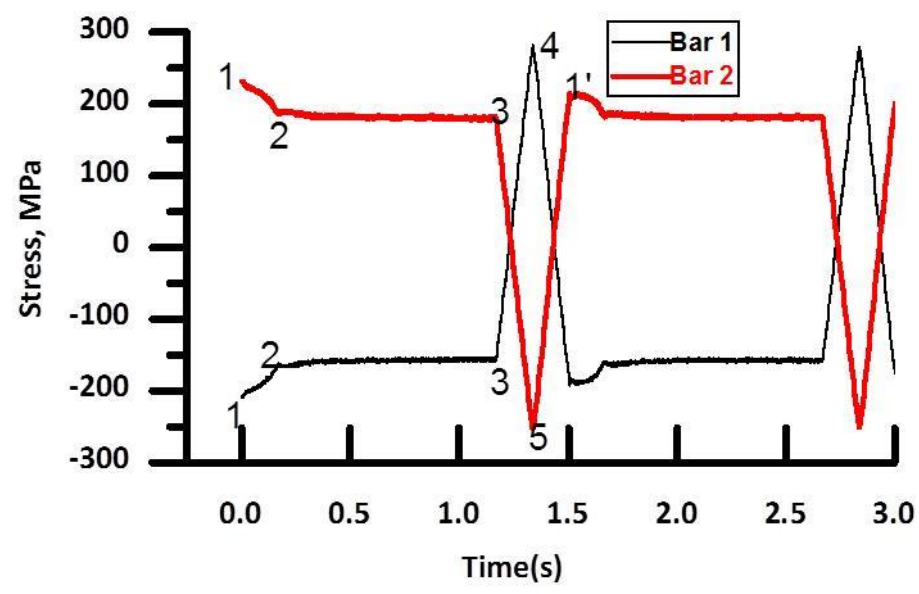

Fig. 12. Stress vs time for Alloy 617 with nominal 150lbs total load and 10min time delay at temperature range of $350^{\circ} \mathrm{C}$ to $650^{\circ} \mathrm{C}$ 

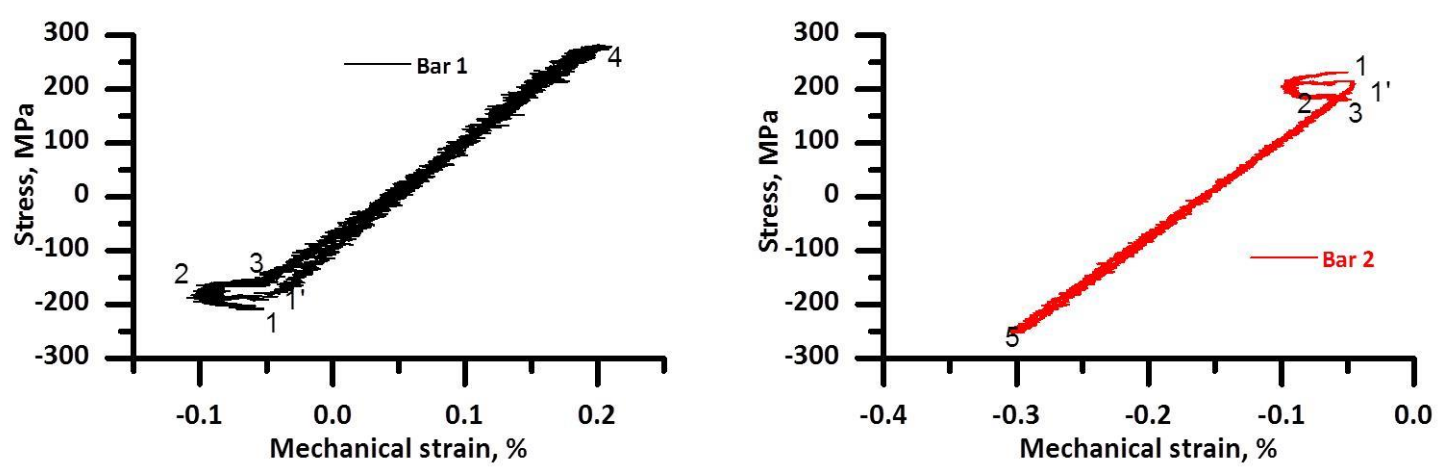

Fig. 13. Stress vs mechanical strain for Alloy 617 with nominal $150 l b s$ total load and $10 \mathrm{~min}$ time delay $\left(350^{\circ} \mathrm{C}\right.$ $\left.-650^{\circ} \mathrm{C}\right)$

\subsubsection{Alloy 617 Test Results Discussion}

In Fig. 9 and Fig. 10, point 1 is the initiation of the thermal heating up ramp for both bars; point 2 is the start of the constant temperature hold period; and point 3 is the end of the hold period and start of the thermal down ramp in bar 1 . Point 4 is the end of the thermal down ramp in bar 1 and point 5 is the end of the hold period in bar 2 and the start of its thermal down ramp. Point 1 is when bar 2 reaches the lower temperature end of the cycle and the cycle repeats with the initiation of the thermal up ramp in both bars. Bars 1 and 2 are at the same temperature from point 1 through the end of the hold period, point 3 . During this period, the mechanical strain in bar 1 and 2 are equal, albeit changing.

As is evident from Fig. 9, the major portion of the ratcheting is driven by the temperature difference between the bars during the cycle when bar 1 is cooling and compressing bar 2 . This trend is reversed when bar 2 cools but the accumulated strain is not as great as during the bar 1 cooling phase. Hence there is a compressive ratchet increment per cycle. This trend is a function of the maximum temperature of the imposed thermal cycle and for the $350-650^{\circ} \mathrm{C}$ cycle in Fig. 13, there is essentially no difference in the accumulated strains in bar 1 and 2 during cooling and thus no ratcheting. Note also that there is also negligible relaxation during the hold period at $650^{\circ} \mathrm{C}$.

At $950^{\circ} \mathrm{C}$ the concept of plasticity and associated yield strength is no longer considered relevant and the deformation can be thought of as visco-plastic flow. This characteristic, which is clear at $950^{\circ} \mathrm{C}$, has attenuated by $800^{\circ} \mathrm{C}$ and may be a contributing factor to the observation that the strain limit code case prediction limits are in much better agreement with the test data at $800^{\circ} \mathrm{C}$ maximum cycle temperature than at an $950^{\circ} \mathrm{C}$ maximum temperature.

\subsection{SS316H TWO-BAR TEST RESULTS}

Two-bar thermal ratcheting tests were performed on SS316H to assess the material response to cyclic thermal loading under two-bar testing conditions at a temperature range of $515-815^{\circ} \mathrm{C}$. The upper temperature of $815^{\circ} \mathrm{C}$ corresponds to the maximum temperature for which allowable stress values are provided in Subsection NH. The results of these tests are listed in Table 6 below.

However, the specimens were found to be slightly buckled after testing, therefore, typical test conditions will be repeated to confirm the strain limits boundaries shown in this report for SS316H. 
Table 6. Summary of two-bar thermal ratcheting experiments on SS316H for temperature range of $515^{\circ} \mathrm{C}$ to $815^{\circ} \mathrm{C} *$

\begin{tabular}{|c|c|c|c|c|c|c|c|c|c|c|}
\hline Test No. & $T 23-1$ & $T 23-2$ & $T 23-3$ & $T 23-4$ & $T 23-5$ & $T 23-6$ & $T 23-7$ & $T 23-8$ & $T 23-9$ & $T 23-10$ \\
\hline $\begin{array}{l}\text { Actual average } \\
\text { total load (lbs) }\end{array}$ & 69 & 528 & 118 & 67.7 & 66.6 & 230 & 331 & -83 & -37 & -35 \\
\hline $\begin{array}{l}\text { Nominal total } \\
\text { load (lbs) }\end{array}$ & 50 & 500 & 100 & 50 & 50 & 200 & 300 & -100 & -50 & -50 \\
\hline $\begin{array}{l}\text { Applied mean } \\
\text { stress, } \mathrm{MPa}\end{array}$ & $\begin{array}{l}4.9 \\
\pm 0.75 \\
\end{array}$ & $\begin{array}{l}37.4 \\
\pm 0.75 \\
\end{array}$ & $\begin{array}{l}8.31 \\
\pm 0.77 \\
\end{array}$ & $\begin{array}{l}4.76 \\
\pm 0.75 \\
\end{array}$ & $\begin{array}{l}4.7 \\
\pm 0.84 \\
\end{array}$ & $\begin{array}{l}16.15 \\
\pm 0.88 \\
\end{array}$ & $\begin{array}{l}23.3 \\
\pm 0.84 \\
\end{array}$ & $\begin{array}{l}-5.8 \\
\pm 0.87 \\
\end{array}$ & $\begin{array}{l}-2.6 \\
\pm 0.92 \\
\end{array}$ & $\begin{array}{l}-2.45 \\
\pm 1.0 \\
\end{array}$ \\
\hline Time delay, $\min$ & 10 & 10 & 10 & 5 & 8 & 10 & 10 & 5 & 5 & 10 \\
\hline $\begin{array}{l}\text { Total No. of } \\
\text { cycles tested }\end{array}$ & 32 & 44 & 34 & 35 & 33 & 33 & 32 & 46 & 34 & 33 \\
\hline $\begin{array}{l}\text { Ratcheting rate } \\
\text { (per cycle), \% }\end{array}$ & -.0014 & .208 & -0.082 & -0.002 & -0.03 & -0.0045 & 0.031 & -0.01 & -0.0046 & -0.163 \\
\hline $\begin{array}{l}\text { Initial stress on } \\
\text { Bar } 1, \mathrm{MPa}\end{array}$ & 18.69 & -91.7 & -108.8 & -142.6 & -70.3 & -109 & -97.5 & -113.1 & -117.2 & -82.74 \\
\hline $\begin{array}{l}\text { Initial stress on } \\
\text { Bar } 2, \mathrm{MPa}\end{array}$ & 35.37 & 164.8 & 124.8 & 154.9 & 80 & 138.2 & 175.9 & 103.4 & 113.1 & 75.5 \\
\hline $\begin{array}{l}\text { Initial residual } \\
\text { total strain, \% }\end{array}$ & 0 & -4.20 & 5.09 & 2.17 & 2.10 & 1.09 & 1.0 & 2.06 & 1.36 & 1.23 \\
\hline $\begin{array}{l}\text { Reference cycle } \\
\text { No. }\end{array}$ & 5 & 5 & 5 & 5 & 5 & 5 & 5 & 5 & 5 & 5 \\
\hline $\begin{array}{l}\text { Min. strain of } \\
\text { the reference } \\
\text { cycle, } \%\end{array}$ & -0.58 & -3.16 & 4.55 & 2.14 & 1.93 & 1.13 & 1.24 & 1.85 & 1.35 & 0.38 \\
\hline $\begin{array}{l}\text { Stress range per } \\
\text { cycle for Bar } 1 \text {, } \\
\mathrm{MPa}\end{array}$ & $\begin{array}{l}267.36 \\
\pm 3.54\end{array}$ & $\begin{array}{l}261 \\
\pm 2.4\end{array}$ & $\begin{array}{l}267.6 \\
\pm 0.1\end{array}$ & $\begin{array}{l}189.4 \\
\pm 10.8\end{array}$ & $\begin{array}{l}237.19 \\
\pm 2.5\end{array}$ & $\begin{array}{l}253 \\
\pm 1.1\end{array}$ & $\begin{array}{l}250.8 \\
\pm 1.8\end{array}$ & $\begin{array}{l}177.5 \\
\pm 6.3\end{array}$ & $\begin{array}{l}173.5 \\
\pm 7.3\end{array}$ & $\begin{array}{l}242 \\
\pm 2.4\end{array}$ \\
\hline $\begin{array}{l}\text { Stress range per } \\
\text { cycle for Bar } 2 \text {, } \\
\mathrm{MPa}\end{array}$ & $\begin{array}{l}262.07 \\
\pm 3.38\end{array}$ & $\begin{array}{l}256.3 \\
\pm 2.01\end{array}$ & $\begin{array}{l}262.6 \\
\pm 0.6\end{array}$ & $\begin{array}{l}183.1 \\
\pm 15.2\end{array}$ & $\begin{array}{l}229.6 \\
\pm 2.04\end{array}$ & $\begin{array}{l}245.4 \\
\pm 0.67\end{array}$ & $\begin{array}{l}243.5 \\
\pm 1.3\end{array}$ & $\begin{array}{l}169 \\
\pm 6.8\end{array}$ & $\begin{array}{l}163.4 \\
\pm 8.1\end{array}$ & $\begin{array}{l}232.1 \\
\pm 2.3\end{array}$ \\
\hline
\end{tabular}


Table 6--continue

\begin{tabular}{|c|c|c|c|c|c|c|c|c|}
\hline Test No. & $T 23-11$ & $T 23-12$ & $T 23-13$ & $T 23-14$ & $T 23-15$ & $T 23-16$ & T23-17 & $T 23-18$ \\
\hline $\begin{array}{l}\text { Actual average } \\
\text { total load (lbs) }\end{array}$ & 313 & 174 & 276 & 324 & -301 & -291 & 148 & -117 \\
\hline $\begin{array}{l}\text { Nominal total } \\
\text { load (lbs) }\end{array}$ & 300 & 150 & 250 & 300 & -300 & -300 & 100 & -100 \\
\hline $\begin{array}{l}\text { Applied mean } \\
\text { stress, } \mathrm{MPa}\end{array}$ & $\begin{array}{l}22.13 \\
\pm 0.75 \\
\end{array}$ & $\begin{array}{l}12.3 \\
\pm 0.77 \\
\end{array}$ & $\begin{array}{l}19.5 \\
\pm 0.91 \\
\end{array}$ & $\begin{array}{l}23.0 \\
\pm 0.97 \\
\end{array}$ & $\begin{array}{l}-21.3 \\
\pm 1.4 \\
\end{array}$ & $\begin{array}{l}-21.0 \\
\pm 1.7 \\
\end{array}$ & $\begin{array}{r}10.5 \\
\pm 1.3 \\
\end{array}$ & $\begin{array}{l}-8.3 \\
\pm 1.4 \\
\end{array}$ \\
\hline Time delay, min & 5 & 10 & 10 & 2 & 2 & 5 & 1 & 1 \\
\hline $\begin{array}{l}\text { Total No. of } \\
\text { cycles tested }\end{array}$ & 47 & 48 & 36 & 36 & 36 & 37 & 37 & 50 \\
\hline $\begin{array}{l}\text { Ratcheting rate } \\
\text { (per cycle), } \%\end{array}$ & 0.017 & -0.031 & 0.008 & 0.0035 & -0.0054 & -0.059 & 0.0014 & -0.001 \\
\hline $\begin{array}{l}\text { Initial stress on } \\
\text { Bar } 1, \mathrm{MPa}\end{array}$ & 23.83 & -83.4 & -112.5 & -112 & -41 & -50 & -87.9 & -3.54 \\
\hline $\begin{array}{l}\text { Initial stress on } \\
\text { Bar } 2, \mathrm{MPa}\end{array}$ & 22.14 & 108.4 & 150 & 158.5 & -1.9 & 11 & 102.3 & -8.2 \\
\hline $\begin{array}{l}\text { Initial residual } \\
\text { total strain, } \%\end{array}$ & -4.11 & 0.82 & -0.868 & -0.46 & -0.24 & -0.55 & -2.83 & -2.66 \\
\hline $\begin{array}{l}\text { Reference cycle } \\
\text { No. }\end{array}$ & 5 & 5 & 5 & 5 & 5 & 5 & 5 & 5 \\
\hline $\begin{array}{l}\text { Min. strain of } \\
\text { the reference } \\
\text { cycle, } \%\end{array}$ & 0.012 & 0.43 & -0.75 & -0.32 & -0.36 & -0.91 & -2.73 & -2.74 \\
\hline $\begin{array}{l}\text { Stress range per } \\
\text { cycle for Bar } 1 \text {, } \\
\mathrm{MPa}\end{array}$ & $\begin{array}{l}195.4 \\
\pm 0.74\end{array}$ & $\begin{array}{l}252.5 \\
\pm 1.3\end{array}$ & $\begin{array}{l}251.6 \\
\pm 1.0\end{array}$ & $\begin{array}{l}76.9 \\
\pm 20.3\end{array}$ & $\begin{array}{l}74.1 \\
\pm 4.3\end{array}$ & $\begin{array}{l}179 \\
\pm 4.4\end{array}$ & $\begin{array}{l}55 \\
\pm 1.7\end{array}$ & $\begin{array}{l}54.2 \\
\pm 1.2\end{array}$ \\
\hline $\begin{array}{l}\text { Stress range per } \\
\text { cycle for Bar } 2 \text {, } \\
\mathrm{MPa}\end{array}$ & $\begin{array}{l}191.3 \\
\pm 0.66\end{array}$ & $\begin{array}{l}247.1 \\
\pm 1.5\end{array}$ & $\begin{array}{l}244.5 \\
\pm 0.4\end{array}$ & $\begin{array}{l}66.8 \\
\pm 21.5\end{array}$ & $\begin{array}{l}60.4 \\
\pm 3.8\end{array}$ & $\begin{array}{l}160.7 \\
\pm 3.5\end{array}$ & $\begin{array}{l}42 \\
\pm 13\end{array}$ & $\begin{array}{l}40 \\
\pm 1.1\end{array}$ \\
\hline
\end{tabular}

Note: *Typical test conditions will be repeated.

Shown below in Fig. 14 is a plot of the above tabulated test results extended to $200 \mathrm{hr}$ based on the measured strain rate. Note the similarity between these results for SS316H at a maximum temperature of $815^{\circ} \mathrm{C}$ and the results for Alloy 617 at a maximum temperature of $950^{\circ} \mathrm{C}$ as shown in Fig. 6. In both cases there is a narrow stovepipe representing the predicted $1 \%$ strain limit from the EPP strain limit code case. And, in both cases, the test results at a high thermal stress range represented by the 10 minute time delay do not agree with the code case prediction. This demonstrates that the restriction of skeletal structures developed for Alloy 617 would be expected to apply to SS316H and other similar materials. 


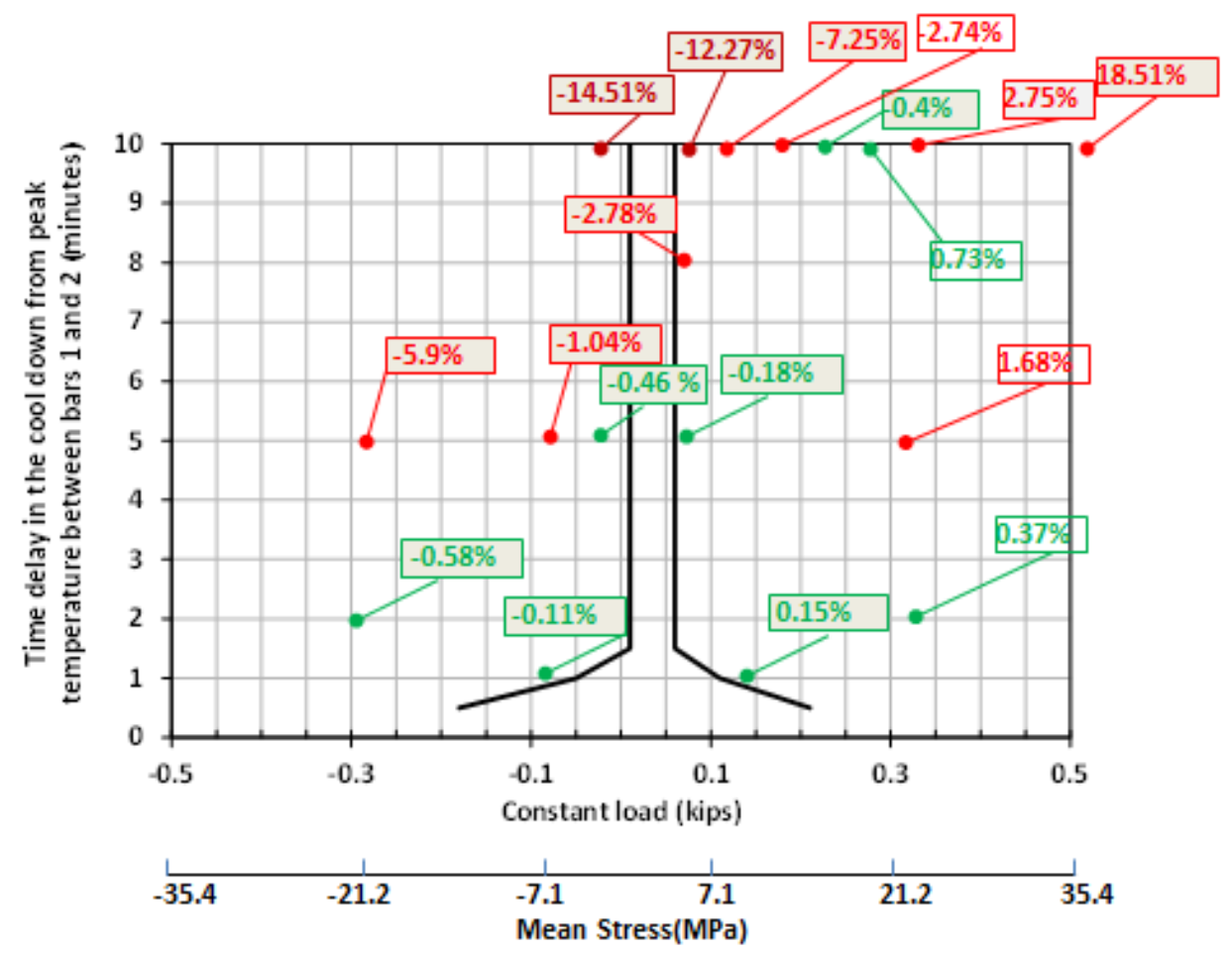

Fig. 14. Two bar test data with $1 \%$ design envelope predictions from the strain limits code case and inelastic analysis ( $\mathrm{SS316H}$ with testing temperature range of $515^{\circ} \mathrm{C}$ to $\left.815^{\circ} \mathrm{C}\right)$. Typical test conditions will be repeated*.

Shown below in Fig. 14 and Fig. 15 are the hysteresis loops and time history for SS316H at a nominal load of 50lbs and a 10 minute time delay. As before, the labeled points on the plots correspond to the loading points shown on Fig. 5 with the time delay in the cooling cycle.
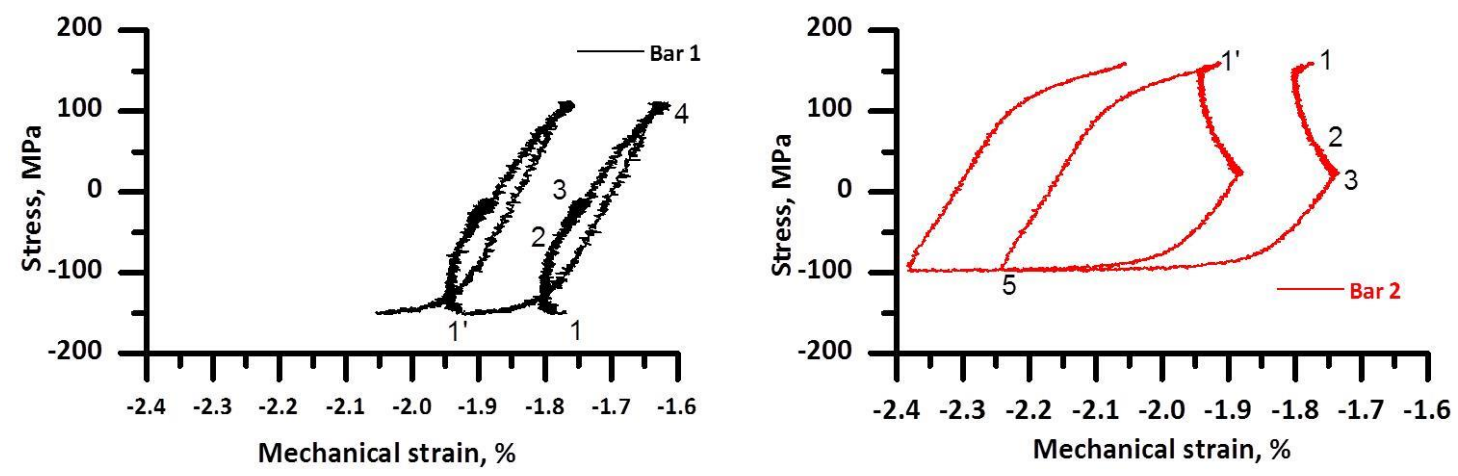

Fig. 15. Stress vs mechanical strain for SS316H for test T23-1 for cyclic temperature range $515-815^{\circ} \mathrm{C}$ 


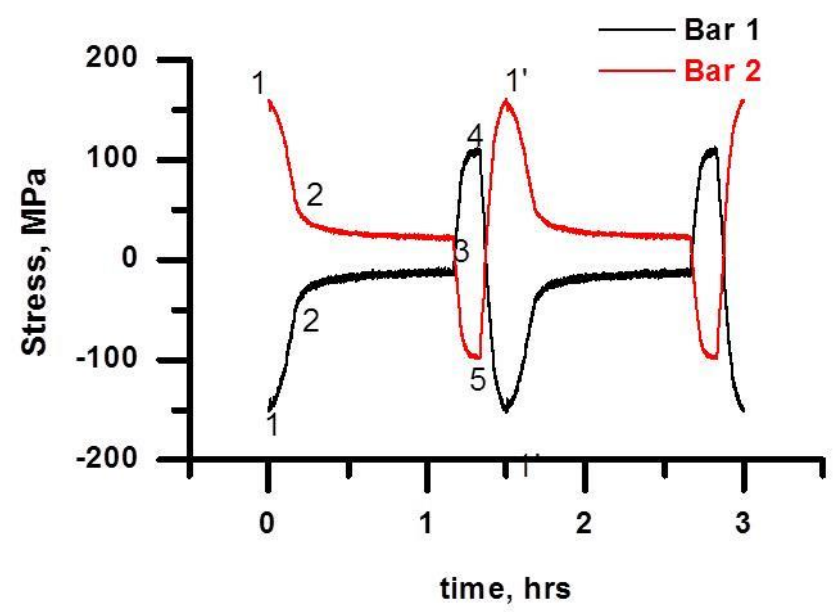

Fig. 16. Stress vs time for $\mathrm{SS316H}$ for test T23-1 for cyclic temperature range $515-815^{\circ} \mathrm{C}$

\section{SUMMARY}

These two-bar tests discussed herein are part of an ongoing series of tests with cyclic loading at high temperatures using specimens representing key features of potential component designs. The initial focus of the two-bar ratcheting test program, to verify the procedure for evaluation of strain limits for Alloy 617 at very high temperatures with tests cycling in the temperature range of $650^{\circ} \mathrm{C}$ to $950^{\circ} \mathrm{C}$ in the has been expanded to respond to guidance from ASME Code committees that the proposed EPP methodology should also apply to other Subsection NH materials throughout their allowed temperature range. To support these objectives, two suites of tests have been accomplished during this reporting period. One suite addresses the issue of the response of Alloy 617 at a lower temperature with tests in range of $500-$ $800^{\circ} \mathrm{C}$ and a few at $350-650^{\circ} \mathrm{C}$. The other suite addresses the response of SS316H up to its current maximum allowed temperature of $1500^{\circ} \mathrm{F}\left(815^{\circ} \mathrm{C}\right)$.

Two-bar thermal ratcheting tests with combinations of applied mean stresses, transient temperature difference and heating and cooling rates were performed at heating and cooling rates of $30^{\circ} \mathrm{C} / \mathrm{min}$ that are comparable to a strain rate of $10^{-5} / \mathrm{sec}$. At high mean stresses in tension the direction of ratcheting was in-phase with the load, e.g. tensile strain ratcheting under high tensile loading; however, at lower loads, strain ratcheting in compression was observed under net tensile mean stresses. The strain accumulation was proportional to the applied thermal load. However, there was a range of applied load in which the high applied thermal loading did not result in significant strain accumulation. Unfortunately, when the proposed EPP strain limit evaluation rules were applied to the loading history for the two-bar configuration in the $650-950^{\circ} \mathrm{C}$ temperature range, the predicted narrow range of low strain accumulation did not coincide with the experimental data. However, by the use of inelastic analysis in conjunction with an analytic "experiment" it was possible to show that the EPP strain limit code case rules could be applied to high temperature structures where the stress and temperature is not uniform throughout - which is the general case.

Interestingly, the suite of tests on Alloy 617 at the lower temperature range of $500^{\circ} \mathrm{C}$ to $800^{\circ} \mathrm{C}$ showed good agreement with the proposed EPP strain limit rules with a much wider band of applied load that exhibited minimal ratcheting. The four tests conducted at the lower temperature range of $350^{\circ} \mathrm{C}$ to $650^{\circ} \mathrm{C}$ showed no ratcheting. The suite of tests on $\mathrm{SS} 316 \mathrm{H}$ at a temperature range of $515^{\circ} \mathrm{C}$ to $815^{\circ} \mathrm{C}$ resembled the results from the tests on Alloy 617 at $650^{\circ} \mathrm{C}$ to $950^{\circ} \mathrm{C}$. Both exhibited a narrow band where the strain 
was limited and neither agreed with the envelope of $1 \%$ predicted strain which is the limit for acceptability under the rules of Subsection NH.

\section{REFERENCES}

Bree, J., (1967), "Elastic -Plastic Behavior of Thin Tubes Subjected to Internal Pressure and Intermittent High-Heat Fluxes with Applications to Fast Nuclear Reactor Fuel Elements," Journal of Strain Analysis Vol. 2, No. 3.

Conway, J. B., et al., (1975), "Thermal Ratcheting Studies of Type 304 Stainless Steel-An Evaluation of a New Test Method," Structural Materials for Service at Elevated Temperature in Nuclear Power Generation, A.O. Schaefer, ed., MPC-1, p. 247, American Society for Mechanical Engineers, New York.

Corum and Blass, (1991), Rules for Design of Alloy 617 Nuclear Components to Very High Temperatures, ASME PVP Vol. 215, p. 147, American Society of Mechanical Engineers, New York, NY.

Carter, P., Jetter, R., Sham, T.-L., (2012a), "Application of Elastic-Perfectly Plastic Cyclic Analysis to Assessment of Creep Strain," PVP 2012 - 28082, American Society of Mechanical Engineers, New York, NY.

Carter, P., Jetter, R., Sham, T.-L., (2012b), “Application of Shakedown Analysis to Evaluation of CreepFatigue Limits," PVP 2012-28083, American Society of Mechanical Engineers, New York, NY.

Carroll L.J., Cabet, C., Wright, R. N., (2010), "The Role of Environment on High Temperature CreepFatigue Behavior of Alloy 617," Proceedings of the ASME 2010 Pressure Vessels and Piping Division Conference, Bellevue, Washington, USA, July 2012, PVP2010-26126, American Society of Mechanical Engineers, New York, NY.

Carroll L.J., Cabet, C., Carroll, M. C. and Wright, R. N., (2013), "The development of microstructural damage during high temperature creep-fatigue of a nickel alloy," Int. J. Fatigue, 47, 115, DOI: 10.1016/j.ijfatigue.2012.07.016

O’Donnell, W., and Porowski, J., (1974), "Upper Bounds for Accumulated Strains Due to Creep Ratcheting,” Journal of Pressure Vessel Technology, Vol. 96, p. 126.

Jetter, R.I., Hollinger G., Pease D., Carter P., Wang Y., and Sham T.-L. (2015), "Background on the Development, Application and Verification of Elevated Temperature Strain Limits Code Case Based on Elastic-Perfectly Plastic Analysis - Abridged Version"

Sartory, W., (1989) "Effect of Peak Thermal Strain on Simplified Analysis Procedures," PVP-Vol. 163, American Society of Mechanical Engineers, New York, NY.

Swindeman, R., Robinson, D., Williams, B. and Thomas, D., (1982) "Two-Bar Thermal Ratcheting Experiments on 21/4Cr-1Mo steel, " ORNL/TM-8001, Oak Ridge National Laboratory, Oak Ridge, TN.

Wang, Y., Sham, T.-L, and Jetter, R .I., (2014), "Two-Bar Thermal Ratcheting for Alloy 617 Part I: Scoping Tests," Journal of Pressure Vessel Technology, ASME, accepted. 
Wang, Y., Sham, T.-L, and Jetter, R .I., (2013), "Progress report on the development of test procedure for the two-bar thermal ratcheting experiment for Alloy 617," ORNL/TM-2013/318, Oak Ridge National Laboratory, Oak Ridge, TN. 


\section{ELECTRONIC DISTRIBUTION}

Name

Baird, S.T.

Carroll, L.

Corwin, W.

Hill, R.N.

Jetter, R.I.

Lara-Curzio, E.

Li, M.

Petti, D.

$\mathrm{Pu}, \mathrm{C}$.

Sham, T.-L.

Sink, C.

Wang, $\mathrm{H}$.

Wang, Y.

Wright, R.N.

ORNL Office of Technical

Information and Classification
Affiliation

ORNL

INL

DOE

ANL

Consultant

ORNL

ANL

INL

University of Tennessee

ORNL

DOE

ORNL

ORNL

INL
Email

bairdst@ornl.gov

Laura.Carroll@INL.gov

william.corwin@nuclear.energy.gov

bobhill@anl.gov

bjetter@sbcglobal.net

laracurzioe@ornl.gov

mli@anl.gov

David.Petti@inl.gov

cpu@utk.edu

shamt@ornl.gov

carl.sink@nuclear.energy.gov

wangh@ornl.gov

wangy3@ornl.gov

richard.wright@inl.gov 